\title{
Neural Injury Alters Proliferation and Integration of Adult-Generated Neurons in the Dentate Gyrus
}

\author{
Julia V. Perederiy, ${ }^{1}$ Bryan W. Luikart, ${ }^{1}$ Eric K. Washburn, ${ }^{1}$ Eric Schnell, $, 2,3$ and Gary L. Westbrook ${ }^{1}$ \\ ${ }^{1}$ The Vollum Institute, Oregon Health and Science University (OHSU), ${ }^{2}$ Portland Veterans Affairs Medical Center, and ${ }^{3}$ OHSU Department of \\ Anesthesiology and Perioperative Medicine, Portland, Oregon 97239
}

\begin{abstract}
Neural plasticity following brain injury illustrates the potential for regeneration in the central nervous system. Lesioning of the perforant path, which innervates the outer two-thirds of the molecular layer of the dentate gyrus, was one of the first models to demonstrate structural plasticity of mature granule cells (Parnavelas et al., 1974; Caceres and Steward, 1983; Diekmann et al., 1996). The dentate gyrus also harbors a continuously proliferating population of neuronal precursors that can integrate into functional circuits and show enhanced short-term plasticity (Schmidt-Hieber et al., 2004; Abrous et al., 2005). To examine the response of adult-generated granule cells to unilateral complete transection of the perforant path in vivo, we tracked these cells using transgenic POMC-EGFP mice or by retroviral expression of GFP. Lesioning triggered a marked proliferation of newborn neurons. Subsequently, the dendrites of newborn neurons showed reduced complexity within the denervated zone, but dendritic spines still formed in the absence of glutamatergic nerve terminals. Electron micrographs confirmed the lack of intact presynaptic terminals apposing spines on mature cells and on newborn neurons. Newborn neurons, but not mature granule cells, had a higher density of dendritic spines in the inner molecular layer postlesion accompanied by an increase in miniature EPSC amplitudes and rise times. Our results indicate that injury causes an increase in newborn neurons and lamina-specific synaptic reorganization indicative of enhanced plasticity. The presence of de novo dendritic spines in the denervated zone suggests that the postlesion environment provides the necessary signals for spine formation.
\end{abstract}

\section{Introduction}

Traumatic brain injury, neurodegeneration, and ischemia all involve denervation, the extent of which contributes to the severity of clinical symptoms. However, brain injury can also stimulate plasticity. An example of such plasticity in the adult brain is the synaptic reorganization following lesions of the entorhinal cortex, which irreversibly interrupt the main excitatory input into the dentate gyrus - the perforant path. The dentate gyrus provides a particularly advantageous model system for examining brain injury because its highly laminated molecular layer segregates inputs from different sources. Perforant path axons from the medial and lateral entorhinal cortex terminate in the middle and outer third of the molecular layer, respectively (HjorthSimonsen and Jeune, 1972; Hjorth-Simonsen, 1972, van Groen et al., 2003), where they synapse with apical dendrites of mature granule cells. When these inputs are severed, remaining intact

\footnotetext{
Received Oct. 8, 2012; revised Jan. 10, 2013; accepted Jan. 15, 2013.

Author contributions: J.V.P. and G.L.W. designed research; J.V.P., B.W.L., and E.S. performed research; E.K.W. contributed unpublished reagents/analytic tools; J.V.P., B.W.L., and E.S. analyzed data; J.V.P. and G.L.W. wrote the paper.

This work was supported by NIH Grant MH46613 and by Oregon Partnership for Alzheimer's Research Tax CheckOff Grant. We thank Oswald Steward for training in the perforant path lesion procedure. We thank Stephanie Kaech-Petrie with the Jungers Center Microscopy Core for assistance with imaging parameters and Sue Aicher, Melissa Williams, Lisa Dirling, and Robert Kayton with the Electron Microscopy Core for tissue preparation and assistance with imaging equipment (supported by NIH Grant P30 NS06180).

The authors declare no competing financial interests.

Correspondence should be addressed to Julia V. Perederiy, Vollum Institute, L474, Oregon Health and Science University, 3181 Southwest Sam Jackson Park Road, Portland, 0R 97239. E-mail: perederi@ohsu.edu.

DOI:10.1523/JNEUROSCI.4785-12.2013

Copyright $\odot 2013$ the authors $\quad 0270-6474 / 13 / 334754-14 \$ 15.00 / 0$
}

fiber systems that also synapse onto mature granule cells reorganize by sprouting and reactive synaptogenesis (Deller and Frotscher, 1997). These changes are maximal within 2 weeks postlesion but gradually stabilize by several months postlesion (Vuksic et al., 2011).

In addition to mature cells, there is ongoing neurogenesis in the rodent dentate gyrus (Kempermann et al., 1997; Cameron and McKay, 2001). A subset of these newborn neurons survive and integrate into the hippocampal circuit, show enhanced short-term synaptic plasticity, and may contribute to normal function of the hippocampus (Dayer et al., 2003; Ge et al., 2008). Newborn cells are exquisitely sensitive to intrinsic and extrinsic stimuli (Tashiro et al., 2007; Balu and Lucki, 2009; Ming and Song, 2011), including changes in network activity triggered by seizures (Parent and Murphy, 2008) or changes in NMDA receptor activity (Cameron et al., 1995; Nacher and McEwen, 2006). Newborn granule cells go through a series of highly stereotyped stages, during which they extend their dendrites through the molecular layer, develop spines, and acquire excitatory synaptic inputs over a period of several weeks (Overstreet Wadiche and Westbrook, 2006). This pattern of functional maturation provides an opportunity to examine whether newborn cells integrate into a recently deafferented circuit.

We focused on newborn granule cells that were dividing at the time of a unilateral perforant path lesion. We hypothesized that new neurons would show enhanced structural plasticity compared to mature neurons. To identify newborn granule cells, we used a POMC-EGFP transgenic mouse in which EGFP expression is driven by transient activity of the pro-opiomelanocortin 
(POMC) promoter (Overstreet et al., 2004). We also used intrahippocampal injections of a retrovirus expressing GFP to label cohorts of newborn neurons at later time points. The completeness of the lesion was confirmed morphologically and by the absence of extracellular field responses in the outer molecular layer in acute brain slices. In the ipsilateral dentate gyrus, lesions caused proliferation of newborn neurons by 2 weeks, followed by a lamina-specific shift in the arrangement of dendritic spines and excitatory synaptic activity by 3 weeks postlesion. Surprisingly, confocal images and immunoelectron micrographs of the denervated zone revealed that newborn neurons formed new dendritic spines postlesion without functional presynaptic input.

\section{Materials and Methods}

Mice. All procedures were performed in accordance with Oregon Health and Science University Institutional Animal Care and Use Committee and the Biosafety Committee protocols and in accord with the NIH guidelines for handling of animals. C57BL6 mice were 6-8 weeks of age at the time of the procedure. Both male and female mice were included and were derived from multiple breedings. POMC-EGFP transgenic mice in C57BL6 background were used for studies of newborn granule cells at 14 days postmitosis, the peak of EGFP expression (Overstreet et al., 2004). We also used retroviral labeling of wild-type C57BL6 mice for visualization of newborn granule cells at 21 days postmitosis, and lentiviral labeling for visualization of mature granule cells at 21 days postlesion. Isoflurane-anesthetized wild-type mice received bilateral stereotaxic injections directly into the dorsal hippocampus on the day of the lesion. For GFP labeling of newborn granule cells, $2 \mu$ l of a replicationdeficient Moloney murine leukemia virus-based retroviral vector (Lewis and Emerman, 1994) designated pRubi (Retrovirus with internal ubiquitin promoter, Luikart et al., 2012) was used. For GFP labeling of mature granule cells, $1 \mu \mathrm{l}$ of a lentiviral vector that contains the HIV-1 Flap element, the human Ubiquitin-c promoter, GFP, and the Woodchuck hepatitis virus posttranscriptional regulatory element (FUGW, Lois et al., 2002; Luikart et al., 2011) was used. Stereotaxic coordinates were as follows: anteroposterior, -1.9 ; lateromedial, \pm 1.1 ; dorsoventral, -2.5 and -2.3 , with an injection rate of $0.25 \mu \mathrm{l}$ per minute. The needle was left in place for $1 \mathrm{~min}$ before withdrawing from the injection site. Viral particles were prepared using established protocols with titers of $1-10 \times 10^{6}$ (Luikart et al., 2011).

Unilateral lesions of the perforant path. Mice were anesthetized in an induction chamber filled with $4 \%$ isoflurane/oxygen and placed in a Kopf stereotaxic apparatus when rendered unresponsive. During surgery, $2 \%$ isoflurane/oxygen mixture was continuously administered through a nose cone. Before incision, the scalp was treated with $2 \%$ lidocaine, iodine mixture, and a double antibiotic. Skull was exposed and a rectangular access window was drilled using a $0.275 \mathrm{~mm}$ diameter carbide drill (Kemmer Praezision) starting $2 \mathrm{~mm}$ lateral to lambda, $1 \mathrm{~mm}$ rostral to the transverse suture, and spanning the width of the hemisphere. Lesion was performed manually using a $15^{\circ}$ aluminum microscalpel (catalog no. 715 , Oasis Medical) with medial to lateral path trajectory at a depth of $4.5 \mathrm{~mm}$. Care was taken to avoid scraping the scalpel along the base of the skull. Lesions alternated between left and right hemisphere, with the contralateral hemisphere serving as the control. In preliminary experiments a few animals did not survive the procedure; however, refinement of the lesion site resulted in no mortality. For MK-801 pretreatment experiments, animals received one intraperitoneal (IP) injection of MK$801(1 \mathrm{mg} / \mathrm{kg}$; catalog no. Asc-027, Ascent Scientific) $20 \mathrm{~min}$ before the lesion. For morphological analysis at 14 and 21 days postlesion, animals were deeply anesthetized with $2 \%$ Avertin (2,2,2-tribromoethanol; Sigma-Aldrich) transcardially perfused with PBS plus $4 \%$ sucrose followed by $4 \%$ paraformaldehyde (PFA) plus $4 \%$ sucrose. Brains were extracted and postfixed overnight in $4 \%$ PFA plus sucrose at $4^{\circ} \mathrm{C}$. After fixation, each brain was split in the coronal plane just anterior to the site of the lesion, and each half was sectioned separately using a vibratome (catalog no. VT-1000S, Leica Microsystems). The rostral half, containing the dorsal hippocampus, was sectioned coronally (100 $\mu \mathrm{m}$ sections), and these sections were used for all morphological analysis. The caudal half, containing the lesion site, was cut horizontally into serial $300 \mu \mathrm{m} \mathrm{sec-}$ tions to assess the extent of lesion. Animals were excluded from analysis if the lesion injured the ventral hippocampus, which led to hippocampal atrophy, or if the lesion was incomplete (Fig. 1). A lesion was considered complete if it spanned the entire height of the entorhinal cortex and was visible even in the most ventral of the horizontal sections.

Immunohistochemistry. Coronal sections $(100 \mu \mathrm{m})$ were permeabilized for 30 min with $0.4 \%$-Triton X-100 in PBS (PBS-T), blocked for 30 min with $10 \%$ horse serum in PBS-T, and stained overnight with primary antibody in $1.5 \%$ horse serum/PBS-T. Stains requiring secondary antibodies were washed in PBS and incubated with secondary antibody in $1.5 \%$ horse serum/PBS-T for $4 \mathrm{~h}$ at room temperature. Sections were rinsed in PBS, mounted on glass slides, and coverslipped using VectaShield with DAPI (catalog no. H-1200; Vector Laboratories). Primary antibodies were as follows: rabbit anti-GFP (Alexa Fluor 488 conjugated; 1:500; catalog no. A21311, Invitrogen); rabbit anti-glial fibrillary acidic protein (GFAP; 1:500, catalog no. Z-0334, Dako); rabbit anti vGlut1 (1:500; catalog no. 135 303, Synaptic Systems); guinea pig anti vGlut2 (1:400; catalog no. 135 404, Synaptic Systems); rabbit anti c-fos (1:1000; Santa Cruz Biotechnologies). Secondary antibodies (1:200 dilution) were as follows: goat anti rabbit (Alexa Fluor 568; catalog no. A11011, Invitrogen), goat anti rabbit (Alexa Fluor 647; catalog no. A21244, Invitrogen); goat anti guinea pig (Alexa Fluor 568; catalog no. A11075, Invitrogen).

Imaging and morphological analysis. Imaging was done on an LSM 7 MP laser scanning microscope (Carl Zeiss MicroImaging). All cell and dendritic spine counting, dendritic arbor tracing, and Sholl analysis were done manually with ImageJ (National Institutes of Health, Bethesda, MD). At 14 days postlesion, sections from POMC-EGFP mice were imaged with $40 \times$ objective, $0.7 \times$ optical zoom, z-stacks of $50 \mu \mathrm{m}, 1 \mu \mathrm{m}$ between planes. At 21 days postlesion, sections from retrovirus- and lentivirus-injected mice were imaged for dendritic arborization with a $40 \times$ objective and $0.7 \times$ optical zoom. Thickness of $z$-stack was varied to accommodate the dendritic span of labeled granule cells, with $1 \mu \mathrm{m}$ distance between image planes. For analysis of spine density of newborn and mature granule cells at 21 days postlesion, sections were imaged with a $63 \times$ objective with $3 \times$ optical zoom. Span of $z$-stack was tailored to the thickness of a single segment of dendrite with $0.5 \mu \mathrm{m}$ distance between planes. Dendritic spines were imaged and analyzed in inner and outer molecular layers of the dentate gyrus. Laser intensity and gain were adjusted between sections to accommodate staining efficiency, but the same microscope settings were used for control (nonlesioned) and lesioned hemispheres within the same section.

Bromodeoxyuridine. For proliferation measurements, two injections of bromodeoxyuridine (BrdU; $300 \mathrm{mg} / \mathrm{kg}$ ) were administered to POMCEGFP mice at three separate intervals postlesion: (1) 0 and $4 \mathrm{~h}$ postlesion (hpl); (2) 16 and $20 \mathrm{hpl}$; and (3) 40 and $44 \mathrm{hpl}$. Animals were perfused with sucrose-containing PBS followed by PFA (see above, Unilateral lesions of the perforant path) at 8,24 , and $48 \mathrm{~h}$ postlesion (i.e., $4 \mathrm{~h}$ after the last BrdU injection). For survival measurements, BrdU injections were at 40 and $44 \mathrm{hpl}$, and the tissue was examined at 1 month postlesion (mpl). For BrdU immunostaining, sections were washed twice in potassium PBS (KPBS) for 10 min each. Antigen retrieval was performed using an acid/ base sequence for $30 \mathrm{~min}$ in $2 \mathrm{~N} \mathrm{HCl}\left(\right.$ at $36^{\circ} \mathrm{C}$ ) followed by $10 \mathrm{~min}$ in $\mathrm{KPBS}, \mathrm{pH} 8.5$, at room temperature. The sections were then permeabilized for $30 \mathrm{~min}$ in $0.4 \% \mathrm{KPBS}-\mathrm{T}$ and blocked for $30 \mathrm{~min}$ with $5 \%$ horse serum (HS) in KPBS-T. Primary antibody (rat anti BrdU; catalog no. ab6326, Abcam) was applied at 1:2000 in 5\% HS/KPBS-T overnight at $4^{\circ} \mathrm{C}$. The sections were washed in KPBS and incubated for $4 \mathrm{~h}$ with Rhodamine Red secondary antibody (goat anti rat; catalog no. 112-295003; Jackson ImmunoResearch) at 1:200 in 5\% HS/KPBS-T at room temperature. The sections were subsequently stained with Alexa Fluor 488-conjugated rabbit anti-GFP (as described above, Immunohistochemistry). Sections were imaged on a Zeiss LSM 780 confocal microscope using a $20 \times$ objective. Z-stacks were $60 \mu \mathrm{m}$, with image planes 2 $\mu \mathrm{m}$ apart. All BrdU-positive cells within the granule cell layer of the dorsal hippocampus were counted for every third $100 \mu \mathrm{m}$ section and averaged for each animal. Because all sections contained both hemispheres, lesion and control hippocampi were processed in parallel. 

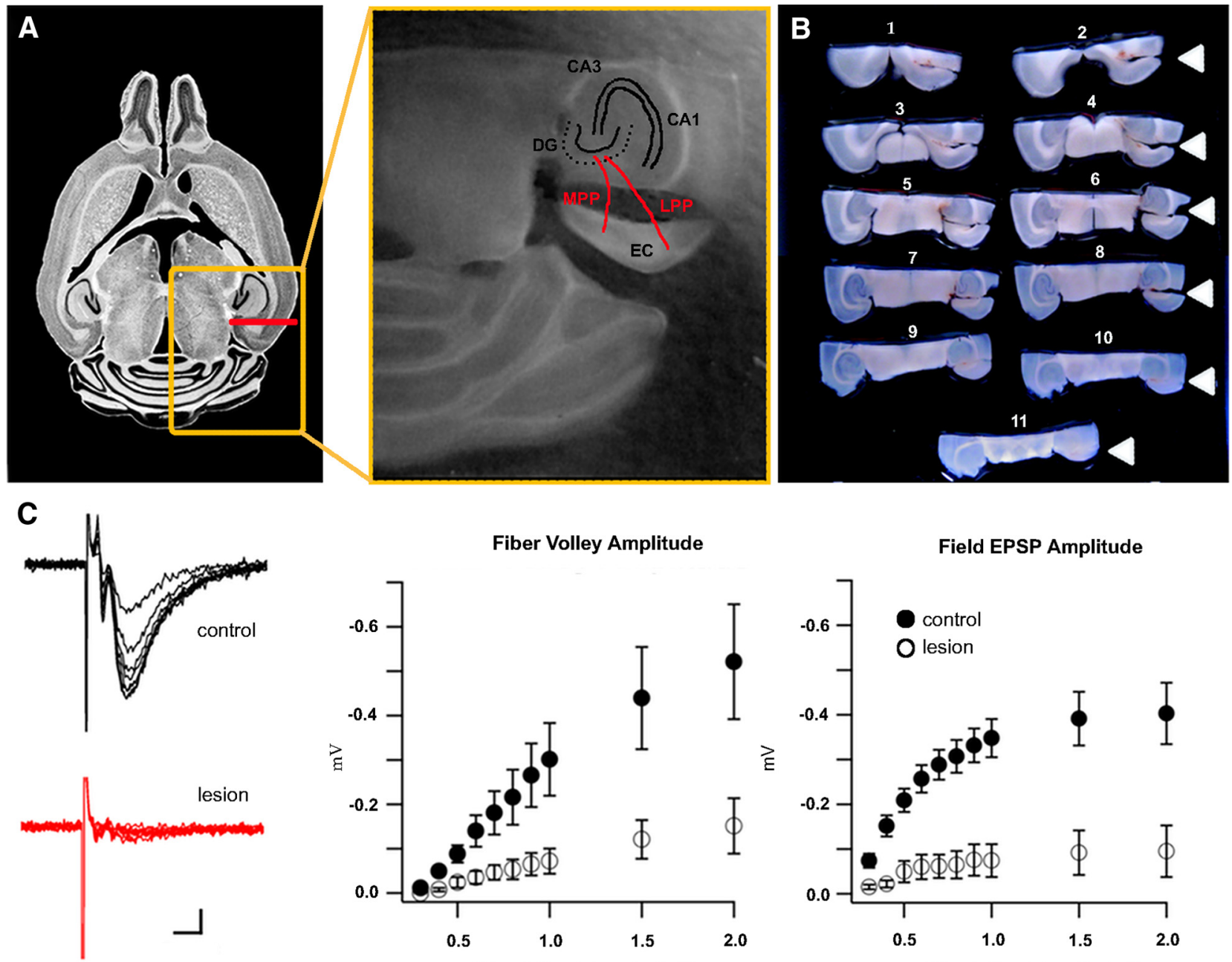

Fiber Volley Amplitude

Field EPSP Amplitude

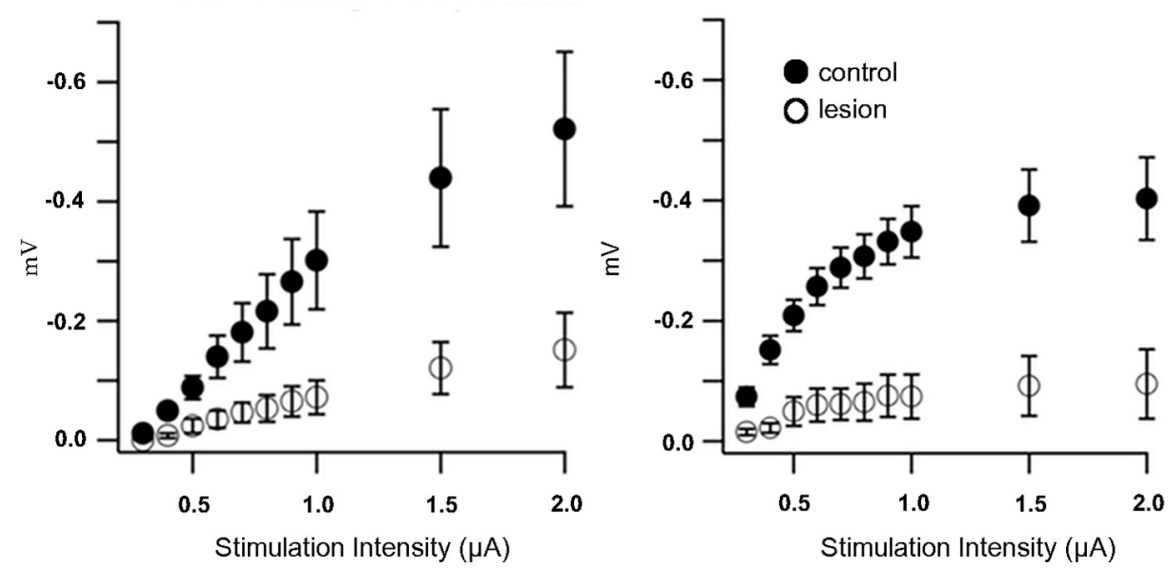

D

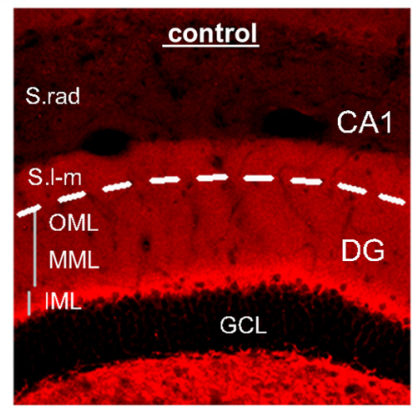

vGlut1

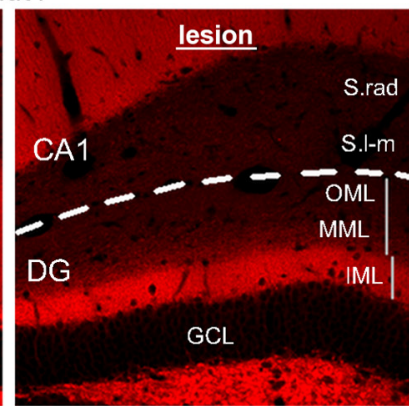

$\mathbf{E}$

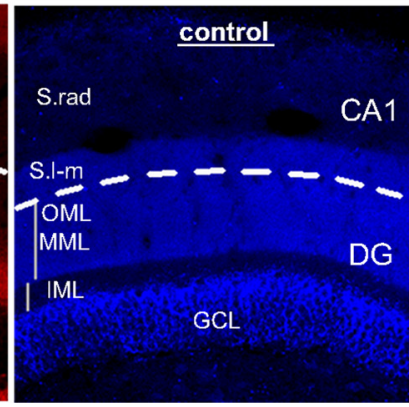

vGlut2

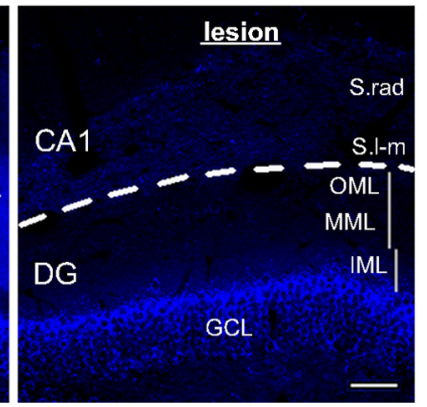

Figure 1. Complete ablation of perforant path axons in the adult dentate gyrus. $A$, A unilateral lesion of the entorhinal cortex $(E C)$ transects the perforant path (red lines). Left, Horizontal section of a mouse brain from Allen Brain Atlas illustrating rostrocaudal position of the lesion (red line). Orange box outlines the position of the middle panel, which shows a close-up of the lesioned perforant path (red lines, MPP and LPP) and hippocampal anatomy. $\boldsymbol{B}$, Lesioned brains were cut in half along the top border of the orange box in $\boldsymbol{A}$, the cerebellum was removed, and the caudal half was horizontally sectioned dorsal to ventral (numbered in order of sectioning). Arrowheads indicate the location of the lesion, which is visible even in the ventral-most section (11). $C$, Left, Example traces of field recordings from an acute brain slice at 14 days postlesion. Whereas in the control dentate gyrus traces showed a robust fiber volley and an increase in the field EPSP with increasing stimulus intensity (black trace), the deafferented dentate gyrus showed no response regardless of stimulation intensity (red trace). Scale bar, $5 \mathrm{~ms} / 50 \mu \mathrm{V}$. Middle, Measurements of fiber volley amplitude across a range of typical stimulation intensities. Fiber volley amplitudes in the deafferented dentate gyrus (white circles) were significantly reduced following lesion, as compared to the contralateral control (black circles, $p<0.05$ ). The same was observed for field EPSPs (right), which were almost entirely absent from the lesioned tissue (white circles) compared to the contralateral control (black circles, $p<0.001)$. D, Left, vGlut1 immunostaining of glutamatergic nerve terminals typically labels the entire dentate molecular layer (IML, MML, 0ML) and stratum lacunosum-moleculare of CA1 (S.I-m). Right, vGlut1 expression was drastically decreased at 21 days postlesion in the denervated zone (MML, OML, CA1) but was unaffected in the intact inner molecular layer (IML, scale bar = $50 \mu \mathrm{m})$. $E$, Left, $\mathrm{GGlut} 2$ expression in the control dentate gyrus was localized to the supragranular zone of the granule cell layer (GCL), the middle/outer molecular layers (MML, $0 \mathrm{ML}$ ), and S.I-m of CA1. Right, At 21 days postlesion, vGlut2 expression was decreased in the denervated region (MML, OML, and S.I-m of CA1), but was unchanged in the supragranular zone (bright band adjacent to the granule cell layer). Dashed lines separate dentate gyrus from CA1. Scale bar, $50 \mu \mathrm{m}$. CA1, Cornu ammonis 1; CA3, cornu ammonis 3; DG, dentate gyrus; EC, entorhinal cortex; GCL, granule cell layer; IML, inner molecular layer; LPP, lateral perforant path; MPP, medial perforant path; MML, middle molecular layer; OML, outer molecular layer; S.I-m, stratum lacunosum-moleculare; S.rad, stratum radiatum. 

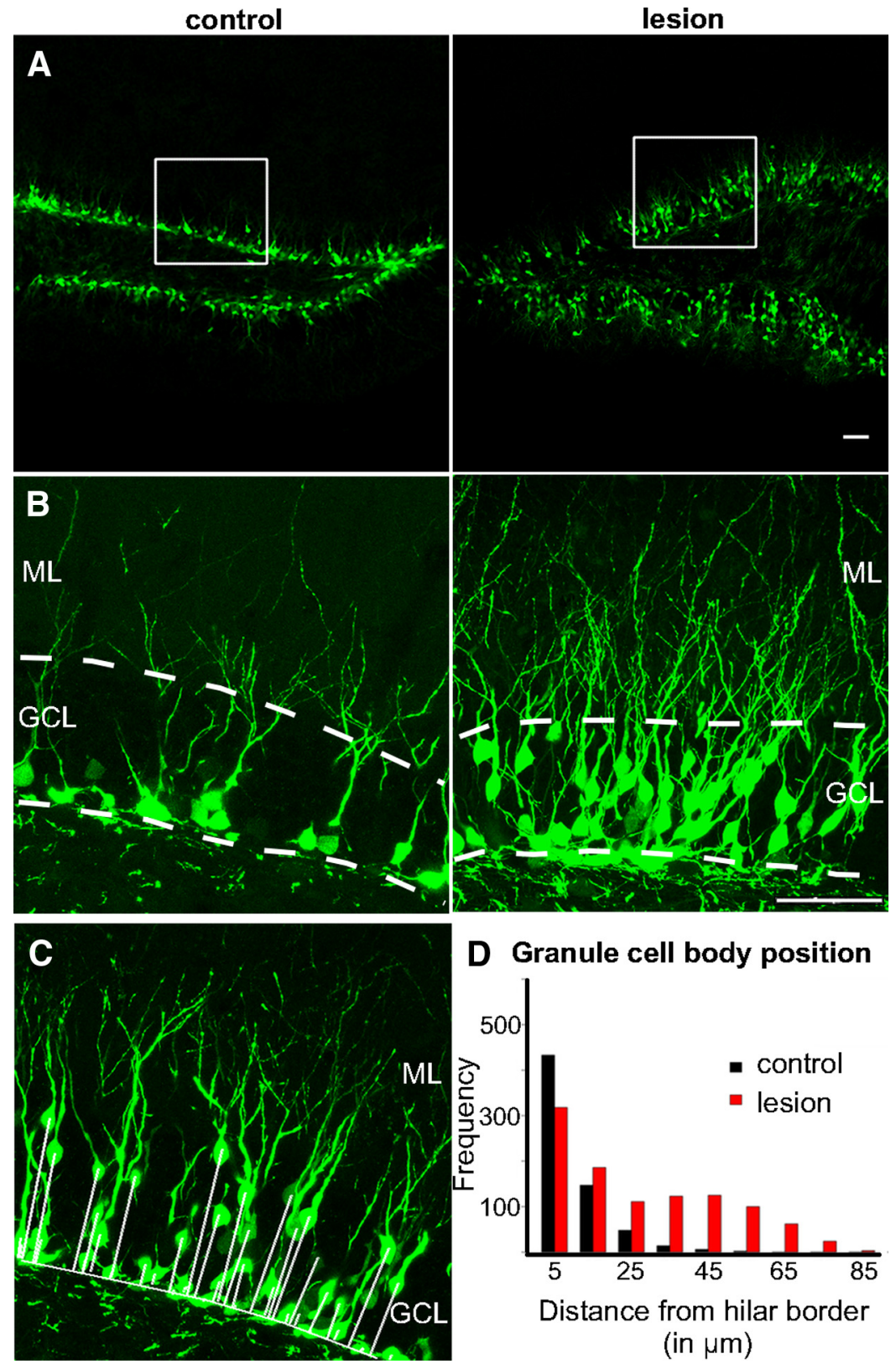

Distance from hilar border

(in $\mu \mathrm{m}$ )

Figure 2. Perforant path lesion triggered proliferation and outward migration of newborn granule cells. $A$, Dentate gyrus (10X magnification) from an adult POMC-EGFP transgenic mouse showed increased proliferation of newborn granule cells at 14 days postlesion of the perforant path (right) compared to the contralateral, nonlesioned control (left). White squares represent area enlarged in $\boldsymbol{B}$. Scale bar, $50 \mu \mathrm{m}$. $\boldsymbol{B}$, Magnification $(40 \times)$ of suprapyramidal blade of the deafferented dentate gyrus (right) showed an increase in the number as well as the outward migration of POMC-EGFP ${ }^{+}$cells postlesion. Labeled cells in the contralateral control were restricted to the subgranular zone (left). Scale bar, $50 \mu \mathrm{m}$. Dashed lines outline the granule cell layer. $\boldsymbol{C}$, Newborn granule cell body position within the granule cell layer was analyzed by measuring the distance between each POMC$\mathrm{EGFP}^{+}$cell body and the hilar border (solid white lines). $\boldsymbol{D}$, Many newborn granule cells in the denervated dentate gyrus migrated away from the subgranular zone (red bars) compared to control (black bars), as revealed in the frequency distribution ( $p<$ 0.0001). GCL, Granule cell layer; ML, molecular layer.

Electrophysiology. Extracellular field potentials and whole-cell recordings were performed at 14 and 21 days postlesion, respectively, from acute slices of dorsal hippocampus at the same anteroposterior level used for morphometric analysis. The animals were deeply anesthetized with an intraperitoneal injection of Avertin (Sigma-Aldrich) and transcardially perfused with ice-cold cutting solution containing $110 \mathrm{~mm}$ choline $\mathrm{Cl}, 7 \mathrm{~mm} \mathrm{MgCl}$, $2.5 \mathrm{~mm} \mathrm{KCl}, 1.25 \mathrm{~mm} \mathrm{NaH}_{2} \mathrm{PO}_{4}{ }^{\star} 2 \mathrm{H}_{2} \mathrm{O}, 0.5 \mathrm{~mm} \mathrm{CaCl}_{2}$, $1.3 \mathrm{~mm} \mathrm{Na}$-ascorbate, and $25 \mathrm{~mm} \mathrm{NaHCO}_{3}$, bubbled with $95 \% \mathrm{O}_{2}-5 \%$ $\mathrm{CO}_{2}$. For field recordings at 14 days postlesion, $400 \mu \mathrm{m}$ coronal slices were made using a Leica vibratome in artificial cerebrospinal fluid
(ACSF) containing $119 \mathrm{~mm} \mathrm{NaCl}, 2.5 \mathrm{~mm} \mathrm{KCl}$, $2.5 \mathrm{~mm} \mathrm{CaCl}_{2}, 1.3 \mathrm{~mm} \mathrm{MgSO}_{4}, 1 \mathrm{~mm} \mathrm{NaH}_{2} \mathrm{PO}_{4}$, $26.2 \mathrm{~mm} \mathrm{NaHCO}_{3}$, and $11 \mathrm{~mm}$ glucose, bubbled with $95 \% \mathrm{O}_{2} / 5 \% \mathrm{CO}_{2}$. After $1 \mathrm{~h}$ recovery, field potentials were recorded with ACSF-filled 2-3 M $\Omega$ glass pipettes placed in the outer molecular layer of the dentate gyrus. In pilot experiments in the deafferented dentate gyrus, we looked for field excitatory postsynaptic potentials (fEPSPs) in multiple locations and at varying depths in the suprapyramidal and infrapyramidal blade, but were unable to elicit responses at the usual range of stimulus intensities. To quantify fEPSPs, we constructed input/output curves after stimulation of the infrapyramidal blade, thus reducing contamination from the adjacent CA1 region. Stimuli were delivered at $0.1 \mathrm{~Hz}$ (duration $100 \mu \mathrm{s}$, A.M.P.I. ISO-Flex constant current stimulator) via a bipolar tungsten electrode (FHC) placed in the outer molecular layer $\sim 150 \mu \mathrm{m}$ deep into slice and $\sim 500 \mu \mathrm{m}$ from the recording electrode. At each stimulus intensity, ten responses were averaged using Igor Pro. The amplitudes of the fiber volley and initial slope of the fEPSPs were graphed relative to the stimulation intensity. For each slice, responses were recorded in the dentate gyrus from the lesioned and nonlesioned hemispheres. For whole-cell recordings at 21 days postlesion, the hemispheres were separated and sectioned at 350 $\mu \mathrm{m}$ in the transverse hippocampal plane. Slices were stored and recordings performed in a solution containing $125 \mathrm{~mm} \mathrm{NaCl}, 2.5 \mathrm{~mm} \mathrm{KCl}$, $2.0 \mathrm{mM} \mathrm{CaCl}_{2}, 1.0 \mathrm{~mm} \mathrm{MgCl}_{2}, 1.25 \mathrm{~mm}$ $\mathrm{NaH}_{2} \mathrm{PO}_{4}, 25 \mathrm{~mm} \mathrm{NaHCO}$, and $25 \mathrm{~mm}$ glucose bubbled with $95 \% \mathrm{O}_{2} / 5 \% \mathrm{CO}_{2}$. For mEPSC recordings, $10 \mu \mathrm{M}$ SR95531 was added to block $\mathrm{GABA}_{\mathrm{A}}$ channels, and $1 \mu \mathrm{M}$ tetrodotoxin was added to block action potentials. The Cs-gluconate whole-cell pipette solution contained $100 \mathrm{~mm}$ gluconic acid, $0.2 \mathrm{~mm}$ EGTA, 5 mM HEPES, 2 mм Mg-ATP, 0.3 mm Li-GTP, $\mathrm{pH}=7.2,295 \mathrm{mOsm}$ ( $\mathrm{pH}$ to 7.2 using $50 \%$ $\mathrm{CsOH}$ for a final concentration of $100-120$ Csgluconate). Series resistance (5-20 M $\Omega$ ) was monitored, and experiments were discarded if the resistance increased by $>10 \mathrm{M} \Omega$. Currents were filtered at $4 \mathrm{kHz}$ and sampled at $40 \mathrm{kHz}$ (MultiClamp 700A Molecular Devices). mEPSCs were detected using a template with rise time of $1 \mathrm{~ms}$, decay time of $6 \mathrm{~ms}$, baseline of $10 \mathrm{~ms}$, length of $30 \mathrm{~ms}$, and a threshold of 3 (AxoGraph X). Captured events were manually reviewed. Rise times were defined as the time between 10 and $90 \%$ of the maximal amplitude.

Electron microscopy. For ultrastructural analysis of mature granule cells at 21 days postlesion, animals were transcardially perfused with PBS followed by a $0.1 \mathrm{M}$ sodium cacodylate buffer containing $1.5 \%$ glutaraldehyde, $1.5 \%$ PFA, $0.05 \mathrm{~m}$ sucrose, and $0.25 \% \mathrm{CaCl}_{2}, \mathrm{pH}$ 7.4. Extracted brains were postfixed overnight in the same solution. The hemispheres were separated along the midline, and each was cut sagittally into $1 \mathrm{~mm}$ sections. The hippocampi from each $1 \mathrm{~mm}$ section were microdissected out and further cut into $1 \times 1 \times 2 \mathrm{~mm}$ blocks that included the dentate gyrus and CA1. Blocks were embedded in coffin mold using Spurr:Epon, polymerized overnight at $60^{\circ} \mathrm{C}$, trimmed, and cut along the long axis into coronal $700 \mathrm{~nm}$ sections using a Leica EM 
UC6 vibratome (Leica Microsystems). For region selection, some sections were placed on glass slides and stained with $0.5 \%$ toluidine blue in $0.5 \%$ sodium tetraborate. Sections from lesioned and nonlesioned hemispheres containing the suprapyramidal blade of the dentate gyrus were embedded in resin and further cut into $70 \mathrm{~nm}$ sections on an ultramicrotome (Leica Microsystems). The sections were placed on 200 square mesh copper/rhodium grids and counterstained with $5 \%$ uranyl acetate and Reynold's lead citrate. The inner and outer molecular layers of the suprapyramidal blade of the dentate gyrus from both lesioned and unlesioned hemispheres were imaged at $13,000 \times$ on an FEI Technai $\mathrm{G}^{2} 12$ BioTWIN microscope at $80 \mathrm{kV}$. Survey images that show reactive astrocytes were acquired at $6800 \times$. Sample sites were selected from inner and outer molecular layers of the suprapyramidal blade of the dorsal dentate gyrus - the same regions that were used for light microscopy and physiological studies. Approximately 10 representative images were collected in a mosaic fashion from the entire span of each molecular layer. At least four nonadjacent sections were used from each animal. The obvious glial reaction in the outer molecular layer (OML) following lesion prevented complete blinding in the analysis.

For ultrastructural analysis of 21-day-old granule cells, we immunolabeled sections from retrovirus-injected animals at 21 days postlesion. Animals were deeply anesthetized with sodium pentobarbital $(150 \mathrm{mg} / \mathrm{kg})$ and, when rendered unresponsive, were transcardially perfused with heparinized saline followed by a $3.8 \%$ acrolein in PFA and 2\% PFA in phosphate buffer (PB) (Hegarty et al., 2010). Tissue blocks containing both dorsal hippocampi were postfixed in 2\% PFA (no acrolein) for 30 min, embedded in agar, and cut coronally into $40 \mu \mathrm{m}$ sections on a vibrating microtome (Leica Microsystems). Hemispheres were not separated for this experiment until just before thin sectioning. Sections were stored in sucrose solution at $-20^{\circ} \mathrm{C}$ until needed. Sections were rinsed $2 \times$ in $0.1 \mathrm{M}$ PB to clear the sucrose solution, placed in $1 \%$ sodium borohydride for 30 min, rinsed with $\mathrm{PB}$ until bubbles were gone, treated with a cryoprotectant solution, and freeze thawed to permeabilize. Once at room temperature, sections were rinsed $2 \times$ in $0.1 \mathrm{M}$ Tris-saline and incubated in $0.5 \%$ BSA for $30 \mathrm{~min}$. Rabbit anti-GFP primary antibody (Millipore, catalog no. AB3080) was applied at 1:1000 for $36 \mathrm{~h}$ at $4^{\circ} \mathrm{C}$. Following incubation, sections were rinsed $3 \times$ in $0.1 \mathrm{M}$ Tris-saline, 5-10 min each, followed by biotinylated goat antirabbit secondary antibody (Vector Labs, catalog no. BA-1000; 1:400 in $0.1 \% \mathrm{BSA}, 30 \mathrm{~min}$, room temperature). Sections were incubated in $\mathrm{ABC}$ solution (Elite Vectastain, Vector Labs; $30 \mathrm{~min}$ ), rinsed with $0.1 \mathrm{M}$ Trissaline, and then treated with diaminobenzidine $-\mathrm{H}_{2} \mathrm{O}_{2}$ solution (5 min). Following washes in $0.1 \mathrm{M}$ Tris-saline and then in $0.1 \mathrm{M} \mathrm{PB}$, sections were incubated in $2 \%$ osmium tetroxide $(60 \mathrm{~min})$, dehydrated, flat embedded in EMBed-812 (catalog no. RT 14120, Electron Microscopy SciencesElectron Microscopy Sciences), and cured at $60^{\circ} \mathrm{C}$ for $48 \mathrm{~h}$ (Fig. $9 \mathrm{~A}$ ). Regions of interest from lesioned and unlesioned hemispheres containing labeled newborn neurons in the suprapyramidal blade of the dentate gyrus were cut out and superglued onto cured resin blanks.
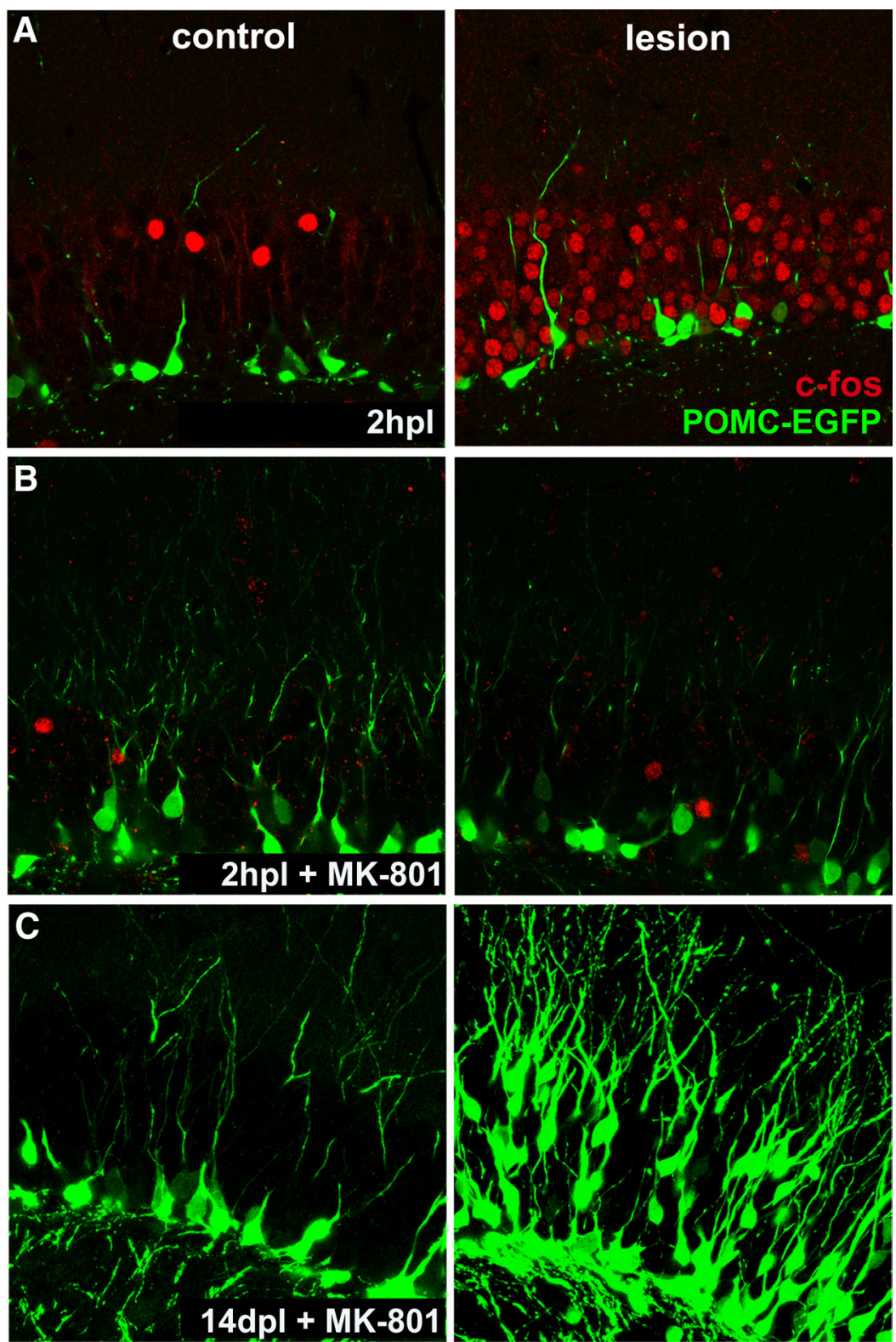

Figure 3. A transient burst of neuronal activity following perforant path lesion. $A$, Transection of perforant path axons triggered widespread expression of the immediate early gene $\mathrm{c}$-fos (right, red) in mature granule cells at $2 \mathrm{~h}$ following injury, indicating increase in network activity. Upregulation of c-fos expression was no longer detected at $6 \mathrm{~h}$ postlesion (not shown), indicating that the activity burst is transient and is associated with axon transection. Note the absence of c-fos immunoreactivity from 14-day-old neurons (POMC-EGFP) that do not yet receive perforant path input. B, c-fos immunoreactivity was abolished by systemic pretreatdid not prevent lesion-induced increase in the number of newborn neurons nor their migration (right, POMC-EGFP). Note also that MK-801 did not affect neurogenesis in the control dentate gyrus (left)

Tissue was thin sectioned on an ultramicrotome (Leica Microsystems) into $75 \mathrm{~nm}$ sections and placed onto nickel/copper mesh grids. Grids were counterstained and sample sites were selected from regions with the densest immunolabeling.

Statistical analysis. All values are expressed as mean \pm SEM. A generalized linear model (GLM) was used for analysis of POMC-EGFP and c-fos cell counts, total dendritic length and arborization, and dendritic spine density. Kolmogorov-Smirnov (KS) test was used to analyze distributions of granule cell dispersion and mEPSC amplitudes and rise times. Repeated-measures ANOVA was used for field potentials, Sholl analysis, and BrdU cell counts. Chi-squared test was used to compare proportions of surviving $\mathrm{BrdU}^{+}$cells. Paired $t$ test was used for analysis of single mEPSCs and electron microscopy (EM) synaptic com- 
control
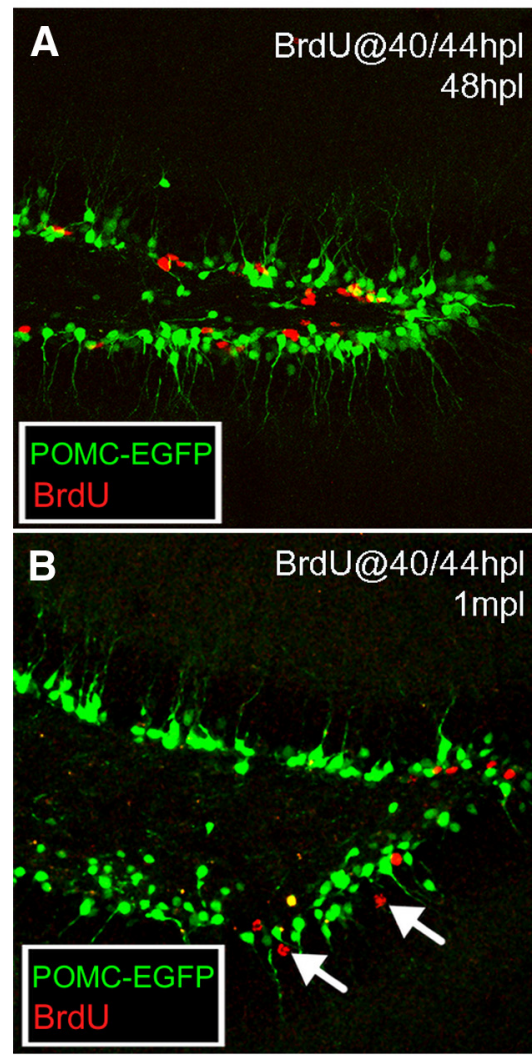

C

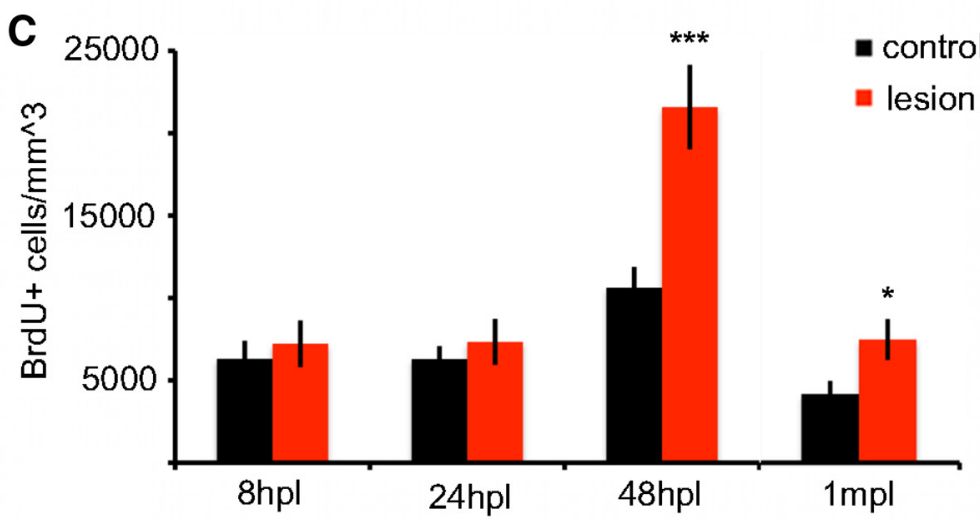

Figure 4. Perforant path lesion caused proliferation of newborn granule cells in the ipsilateral dentate gyrus, but it did not affect the fraction that survived. Compressed $60 \mu \mathrm{m}$ z-stacks from dentate gyrus of a POMC-EGFP transgenic mouse with newborn neurons labeled in green and immunolabeling for BrdU in red. $A$, To examine granule cell proliferation, BrdU was injected at 40 and $44 \mathrm{~h}$ postlesion and tissue was evaluated at $48 \mathrm{~h}$ postlesion. In the control dentate gyrus (left), a few BrdU ${ }^{+}$cells were present near the hilar border. In the deafferented dentate gyrus (right), many BrdU ${ }^{+}$cells were present throughout the deafferented region (MML, OML, CA1), representing new granule cells as well as proliferating glia. To evaluate granule cell proliferation, $\mathrm{BrdU}^{+}$cells were counted only in the granule cell layer. Scale bar, $50 \mu \mathrm{m}$. B, To measure granule cell survival, BrdU was injected at 40 and $44 \mathrm{~h}$ postlesion, and tissue was evaluated at 1 month postlesion. As at $48 \mathrm{~h}$, there were more BrdU ${ }^{+}$cells (red) in the granule cell layer on the lesioned side as well (right) compared to the control dentate gyrus (left). BrdU ${ }^{+}$cells were more widely dispersed within the granule cell layer (arrows), consistent with neuronal maturity, whereas $\mathrm{BrdU}^{+}$glia were no longer apparent in the molecular layer. Scale bar, $50 \mu \mathrm{m}$. C, The number of BrdU ${ }^{+}$cells within the granule cell layer was unaffected by the lesion when measured at 8 or $24 \mathrm{~h}$ (8hpl or $24 \mathrm{hpl}$, respectively), but was dramatically increased in the deafferented dentate gyrus (red bars) at $48 \mathrm{~h}$ postlesion (48hpl, $p<0.001)$. The number of BrdU ${ }^{+}$cells remained elevated following lesion for at least 1 month $(1 \mathrm{mpl}, p<0.05)$. The percentage of $0.05,{ }^{* * *} p<0.001$. Yellow cells are the result of z-stack compression and do not indicate colocalization with POMC-EGFP. VS2. CA1, Cornu ammonis 1; GCL, granule cell layer; MML, middle molecular layer; 0ML, outer molecular layer. surviving cells (ratio of counts $48 \mathrm{hp} / 1 \mathrm{mpl}$ ) did not differ between the two hemispheres ( $34.7 \%$ lesioned vs.39.6\% nonlesioned). ${ }^{*} p<$

\section{Results}

The perforant path from the entorhinal cortex is the major afferent input to hippocampus, forming excitatory synapses in the outer two-thirds of the molecular layer of the dentate gyrus. To examine the impact of deafferentation on adultgenerated newborn neurons in the dentate gyrus, we made unilateral surgical lesions of the perforant path in young adult mice (Fig. 1A). Because surgical lesions can be variable, we verified the completeness of each lesion by serially sectioning the caudal half of the brain from dorsal to ventral in the horizontal plane (Fig. $1 B$ ). In this example of a complete lesion at 14 days postlesion $(\mathrm{dpl})$, the location of the surgical cut was visible even in the ventral-most horizontal sections of the caudal half of the mouse brain (arrowheads). To account for systemic factors such as anesthesia or surgical stress, the contralateral dentate gyrus was used as an in-animal control. Animals with incomplete lesions or with damaged hippocampi were excluded from the analysis. We confirmed degeneration of perforant path fibers by extracellular field recordings in acutely prepared coronal brain slices at $14 \mathrm{dpl}$. We measured the fiber volley, which represents action potential propagation in perforant path axons, and field excitatory postsynaptic potentials, which reflect granule cell depolarization in response to excitatory synaptic transmission. As expected, stimulation contralateral to the lesion evoked a short latency fiber volley followed by a fEPSP as recorded with an extracellular electrode in the outer molecular layer. However, both the fiber volley and fEPSP amplitudes were greatly reduced or completely absent on the lesioned side (Fig. $1 C)$ over a wide range of stimulation intensities. For example, at $1.0 \mu \mathrm{A}$ stimulation intensity, the fiber volley amplitude was decreased $76.1 \%$ (control, $-0.30 \mathrm{mV}$; lesion, - $0.07 \mathrm{mV} ; p<0.05$, repeatedmeasures ANOVA; $n=12$ slices from 5 animals). Similarly, the fEPSP amplitude at this stimulation intensity was decreased $88.2 \%$ (control, - $0.34 \mathrm{mV} / \mathrm{ms}$; lesion, - $0.04 \mathrm{mV} /$ $\mathrm{ms}, p<0.0001$, repeated-measures ANOVA; $n=12$ slices from 5 animals).

To assess the integrity of perforant path nerve terminals postlesion, we immunolabeled the vesicular glutamate transporters vGlut 1 and vGlut2, which often show complementary distributions at position. The number of samples where $n=$ number of animals are included for every experiment. Animals were not used for multiple experiments. Significance cutoff was $p<0.05$. The $p$ values are reported in the text. excitatory synapses. vGlut1 is expressed in perforant path fibers as well as in the mossy fibers of dentate granule cells, whereas vGlut2 is expressed in hilar mossy cells and extrahippocampal 
A
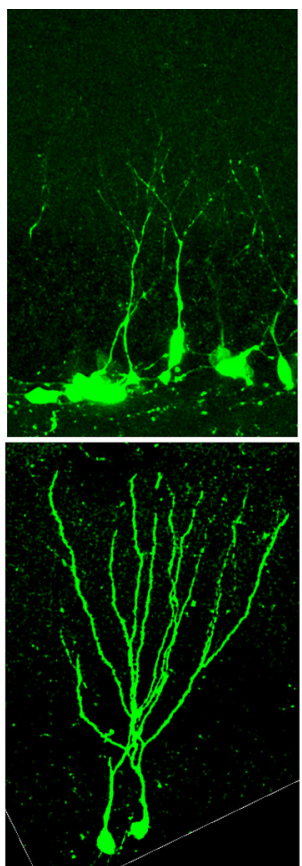

C

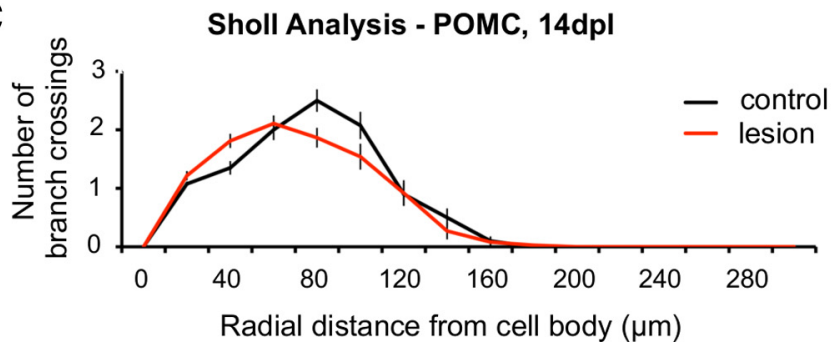

lesion

14-day-old granule cells (POMC-EGFP)

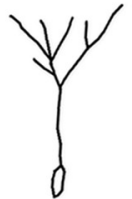

21-day-old granule cells (Retrovirus)

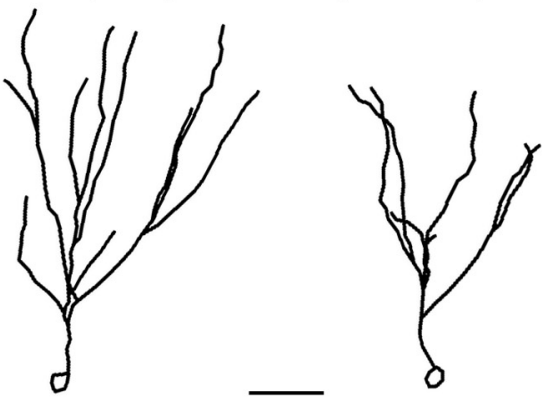

B
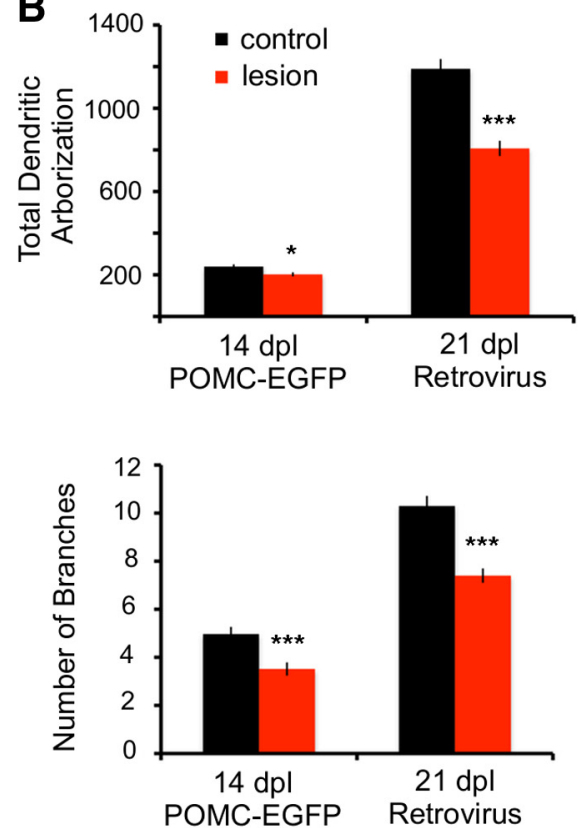

D

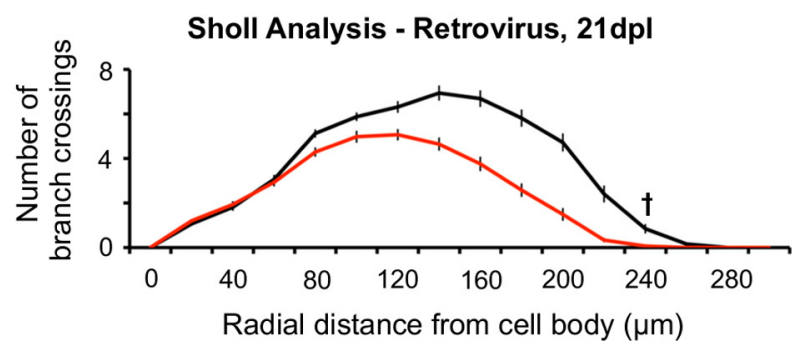

Figure 5. Perforant path lesion reduced outgrowth and complexity of newborn granule cell dendrites. A, At 14 days postlesion, dendritic arbors of 14 -day-old POMC-EGFP ${ }^{+}$neurons were greatly reduced in total length and complexity on the lesioned side (top right) compared with the contralateral control (top middle). Top left shows a projection of a confocal $z$-stack from which the control cell was traced. Bottom, Retrovirally infected 21-day-old granule cells at 21 days postlesion also showed reduced dendritic outgrowth in the deafferented dentate gyrus (bottom right). Bottom left shows a projection of a confocal z-stack from which the control granule cell was traced. Scale bar, $50 \mu \mathrm{m}$. B, Top, At both 14 and 21 days postlesion the total dendritic length was significantly decreased ( $p<0.05, p<0.001$ ). Bottom, The number of branches in 14-day-old and 21-day-old granule cells (POMC-EGFP and Retrovirus, respectively) was also decreased on the lesioned side $(p<0.001) . C, D$, Sholl analysis of 14-day-old POMC-EGFP ${ }^{+}$granule cell dendrites at 14 days postlesion showed an apparent shift in dendritic complexity toward the granule cell bodies/inner molecular layer, where incoming fibers are intact (but these changes did not reach significance). However, Sholl analysis of retrovirally infected 21-day-old granule cell dendrites at 21 days postlesion showed a decrease in complexity of distal dendritic segments in the deafferented zone $\left({ }^{\dagger} p<0.001\right)$, relative to granule cells in the contralateral dentate gyrus. ${ }^{*} p<0.05$; ${ }^{* * *} p<0.001$. Scale bars in $A, 50 \mu \mathrm{m}$.

inputs from the supramammillary nuclei (Leranth and Hajszan, 2007). At $21 \mathrm{dpl}$, vGlut1 immunolabeling was relatively homogeneous throughout the molecular layer and hilus, but was not present within the granule cell layer (Fig. $1 D$, left). In the deafferented dentate gyrus there was no detectable labeling in the outer two-thirds of the molecular layer (OML staining ratio lesion/control $=0.17, n=5$ animals). Labeling was preserved in the inner molecular layer (IML), which was somewhat broader than the control as observed previously (Deller et al., 1996). vGlut2 immunolabeling showed the expected expression in a narrow band of the supragranular layer (Boulland et al., 2009), but no detectable expression in the denervated zone (Fig. 1E, right). The lack of vGlutl (or vGlut2) staining postlesion is consistent with complete perforant path transection, and it is also consistent with the lack of a crossed entorhinodentate pathway in the mouse (van Groen et al., 2002; Del Turco et al., 2003; Deller et al., 2007).
Proliferation and migration of newborn neurons following perforant path lesion

To examine the response of newborn neurons following perforant path lesion, we used POMC-EGFP transgenic mice that transiently label newborns neurons at $\sim 10-14$ days postmitosis (Overstreet et al., 2004, Fig. 2A, left). There was an increase in the number of $\mathrm{EGFP}^{+}$cells in the dentate gyrus postlesion (Fig. 2A, right) compared to the contralateral control (Fig. $2 A$, left) in the same animal (control, $74 \pm 11 \times 10^{3}$ cells $/ \mathrm{mm}^{3}$; lesion, $107 \pm$ $22 \times 10^{3}$ cells $/ \mathrm{mm}^{3} ; p<0.05$, GLM; $n=8$ animals). In addition to the increased number, $\mathrm{EGFP}^{+}$cells were no longer limited to the subgranular zone but had migrated within the granule cell layer as shown in the close-up of the suprapyramidal blade of the dentate gyrus (Fig. $2 B$ ). To quantify the migration, we measured the perpendicular distance between the center of each EGFP ${ }^{+}$cell body and the border between the subgranular zone and hilus (Fig. $2 C)$. Newborn granule cells in the deafferented dentate gyrus were nearly three times farther from the hilar border than those in the contralateral control, thus shifting the distribution of new- 
A control

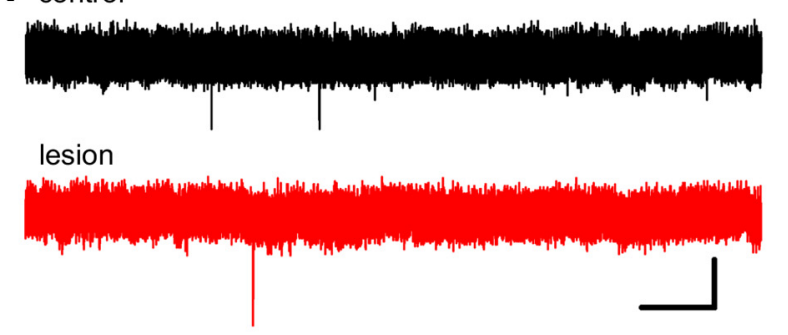

B

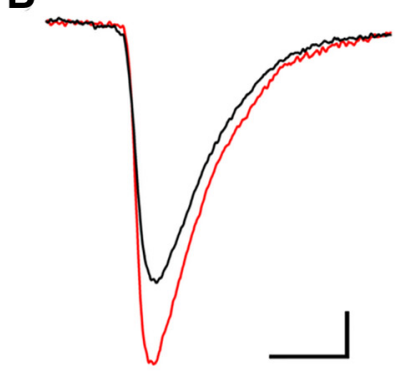

C

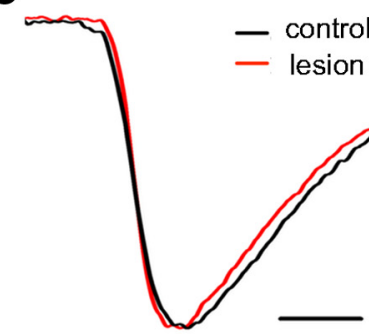

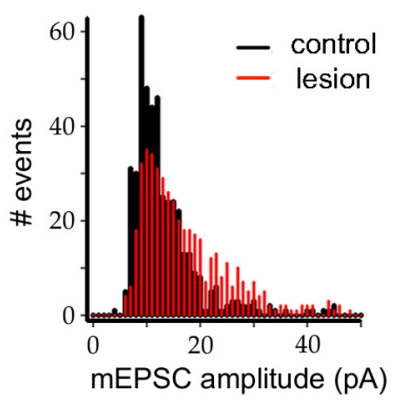

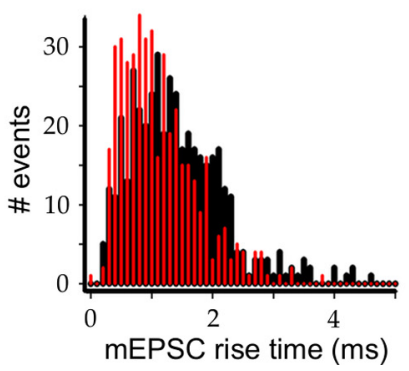

Figure 6. Perforant path lesion decreased mEPSC frequency, but the amplitudes were increased and rise times were faster in newborn granule cells. $\boldsymbol{A}$, Left, Representative traces of spontaneous activity in 21-day-old granule cells at 21 days postlesion (scale bar, 2 s/20 pA). Granule cells in the deafferented dentate gyrus (bottom trace) had fewer miniature EPSCs than the contralateral control (top trace). Right, mEPSC frequency on the lesioned hemisphere was significantly lower $(p<0.05)$. $\boldsymbol{B}$, Left, Exemplar traces of mEPSCs from lesioned and control hemispheres (scale bar, $5 \mathrm{~ms} / 2 \mathrm{pA}$ ). Miniature events were larger in granule cells from the lesioned hemisphere (red trace) than from the control (black trace). Middle, The amplitude distribution of mEPSCs was shifted to the right in the lesioned hemisphere (red bars, $p<0.0001$ ). Right, Mean mEPSC amplitude was significantly increased following lesion ( $p<0.05)$. C, Left, mEPSCs in 21-day-old granule cells from the deafferented (red) showed faster rise times than control (black; scale bar, $2 \mathrm{~ms}$ ). Middle, Distribution of mEPSCs rise times. Lesion shifted the distribution to the left (red bars) relative to the contralateral control (black bars; $p<0.0001)$. Right, mEPSC rise times were significantly faster following lesion $(p<0.01)$. ${ }^{*} p<$ $0.05,{ }^{* *} p<0.01$.

born neurons within the granule cell layer to the right (Fig. $2 D$; control, $9.16 \pm 0.81 \mu \mathrm{m}$; lesion, $25 \pm 2.47 \mu \mathrm{m}, p<0.0001$, KS test; $n=8$ animals).

Changes in neuronal activity can increase the number of newborn neurons (Parent and Murphy, 2008), and thus we tested whether the lesion caused an acute change in neuronal activity. Dentate granule cells showed a transient increase in activity for $2-4 \mathrm{~h}$ postlesion as measured by c-fos immunoreactivity (Fig. $3 A$; control, $8.2 \pm 10$ cells/slice; lesion, $50.92 \pm 11.18$ cells/slice; $p<$ 0.001, GLM; $n=6$ animals; Haas et al., 1999). The increase in c-fos was most prominent in mature granule cells, as newborn neurons labeled with POMC-EGFP have yet to receive perforant path input (Fig. 3A, right). Although the NMDA receptor antagonist MK-801 (1 mg/kg IP) blocked the postlesion activation of mature granule cells (Fig. $3 B$; control, $2 \pm 0.95$ cells/slice; lesion, $1.12 \pm 0.46$ cells/slice; N.S., GLM; $n=6$ animals; Nitsch and Frotscher, 1992), it did not block the proliferation of newborn granule cells observed at 14 days postlesion (Fig. 3C; control, $75 \pm 24 \times 10^{3}$ cells $/ \mathrm{mm}^{3}$; lesion, $107 \pm 18 \times 10^{3}$ cells $/ \mathrm{mm}^{3}, p<$
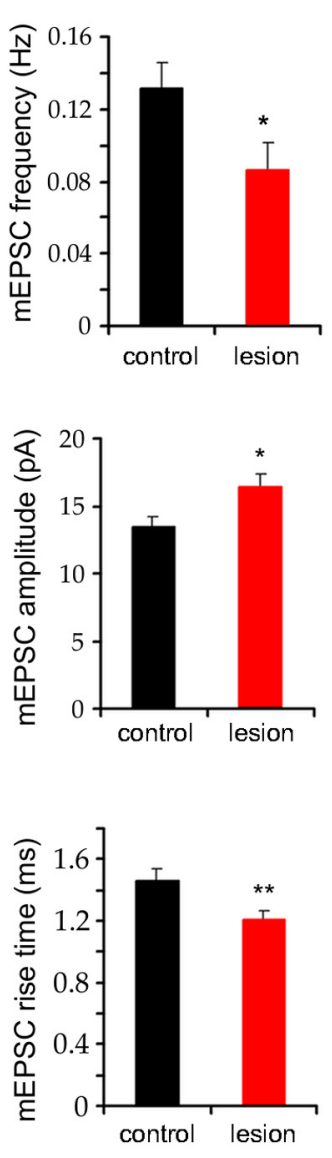

0.05, GLM; $n=9$ animals). Similarly, MK-801 pretreatment did not affect the lesion-induced outward migration of newborn granule cells (Fig. 3C; control, $9.16 \pm 0.84 \mu \mathrm{m}$; lesion, $21.3 \pm 3.57 \mu \mathrm{m}$, $p<0.0001$, KS test; $n=8$ animals) or neurogenesis in the contralateral control dentate gyrus. Thus lesion-induced proliferation and migration of newborn neurons could not be attributed to the transient release of glutamate from lesioned perforant path axons.

The increase in newborn neurons on the side of the lesion could result either from an increase in proliferation or an increase in survival. Thus we injected BrdU into lesioned mice to label dividing cells in the dentate gyrus. Two injections of BrdU, separated by $4 \mathrm{~h}$, were used to saturate labeling during one cell cycle (see Materials and Methods). We counted the number of BrdU-labeled cells within the granule cell layer $4 \mathrm{~h}$ after the last BrdU injection (at 8,24 , and $48 \mathrm{~h}$ postlesion) as an estimate of proliferation and at 1 month postlesion as an estimate of survival. At 8 and $24 \mathrm{~h}$ postlesion there was only a slight increase in BrdU-labeled cells (Fig. 4C; 8 h: control, $6.3 \pm 1.1 \times 10^{3}$ cells $/ \mathrm{mm}^{3}$; lesion, $7.2 \pm 1.4 \times 10^{3}$ cells/ $\mathrm{mm}^{3}$, NS, ANOVA; $n=4$ animals; $24 \mathrm{~h}$ : control, $6.2 \pm 0.8 \times 10^{3}$ cells $/ \mathrm{mm}^{3}$; lesion, $7.3 \pm 1.4 \times 10^{3}$ cells $/ \mathrm{mm}^{3}$, NS, ANOVA; $n=5$ animals). However, by $48 \mathrm{~h}$ postlesion there was a doubling of BrdU-labeled cells (Fig. 4A,C; control, $10.6 \pm 1.3 \times 10^{3}$ cells $/ \mathrm{mm}^{3}$; lesion, $21.6 \pm 2.6 \times 10^{3}$ cells $/ \mathrm{mm}^{3}, p<0.001$, ANOVA; $n=7$ animals), suggesting that the increase in $\mathrm{EGFP}^{+}$cells was the result of a lesion-induced proliferative response. As expected, the majority of $\mathrm{BrdU}^{+}$cells were in the subgranular zone at the hilar border. As shown in Figure 4A, right, BrdU-labeled cells were also observed in the denervated region, consistent with a glial response following lesion (Hailer et al., 1999). At 1 month postlesion there was a corresponding increase in surviving $\mathrm{BrdU}^{+}$cells (Fig. $4 B$; control, $4.2 \pm 0.8 \times 10^{3}$ cells/ $\mathrm{mm}^{3}$; lesion, $7.5 \pm 1.2 \times 10^{3}$ cells $/ \mathrm{mm}^{3}, p<0.05$, ANOVA; $n=$ 7 animals). Despite the increase in proliferation, the percentage of surviving newborn granule cells [( counts at $48 \mathrm{~h}$ )/(counts at 1 month)] was similar between hemispheres (Fig. 4C; control, $39.6 \%$; lesion, $34.7 \%$, NS, $\chi^{2}$ test), suggesting that the survival rate was not altered by the lesion.

\section{Dendritic outgrowth and synapse formation postlesion}

Adult-generated newborn granule cells extend dendrites into the inner molecular layer by 2 weeks postmitosis but have yet to receive excitatory inputs. By the third week, the dendrites reach the outer two-thirds of the molecular layer and are contacted by the perforant path (Overstreet-Wadiche and Westbrook, 2006). Unlike mature granule cells that are denervated by the perforant path lesion, we analyzed newborn cells that were dividing at the 
time of the injury. This approach allowed us to examine the effect of the perforant path lesion on dendritic outgrowth and synapse formation after perforant path fibers have already degenerated. Dendritic arbors at 14 days postlesion were measured using POMC-EGFP mice. Dendrites and synaptic activity at 21 days postlesion were measured in neurons that had been labeled with GFP using retroviral vectors at the time of lesion ( $\mathrm{pRubi}$; see Materials and Methods). Examples of labeled neurons are shown in Figure $5 A$, left, As expected, the total length and branch number of dendrites increased between days 14 and 21 in the control (Fig. 5 $A$, middle). However, the growth of dendrites and branches was significantly less postlesion (Fig. 5A, right, and Fig. 5B; 14 days: control, $239.5 \pm 26.7 \mu \mathrm{m}$; lesion, $202.0 \pm 26.4 \mu \mathrm{m}, p<0.05$, GLM, $n=5$ animals, 7-15 neurons per dentate gyrus; 21 days: control, $1189.7 \pm 119.3 \mu \mathrm{m}$; lesion, $807.2 \pm 109.8 \mu \mathrm{m}, p<0.0001$, GLM, $n=5$ animals, 5-10 neurons per dentate gyrus). Sholl analysis of all traces revealed that dendritic complexity was not affected in 14-day-old neurons when the dendrites are confined to the inner molecular layer (Fig. 5C, NS, repeatedmeasures ANOVA), but there was a significant reduction in the distal dendritic complexity in 21-day-old neurons (Fig. $5 D, p<0.001$, repeated-measures ANOVA) corresponding to the denervated zone.

In addition to the perforant path, dentate granule cells receive commissural/associational excitatory inputs located in the inner molecular layer that are not interrupted by the lesion and thus could provide synaptic input to adult-generated newborn neurons. To examine this possibility, we recorded miniature excitatory synaptic currents (mEPSCs) from 21-day-old granule cells that had been GFP-labeled with the pRubi retrovirus on the day of the lesion. mEPSCs were present at 21 days postlesion, but the frequency was decreased in the denervated dentate gyrus compared to the contralateral control (Fig. 6A; control, $0.13 \pm$ $0.01 \mathrm{~Hz}$; lesion, $0.09 \pm 0.02 \mathrm{~Hz}, p<0.05$, paired $t$ test; $n=11$ and 12 neurons, respectively). The mEPSC amplitude was increased on the lesioned side (Fig. $6 \mathrm{~B}$, right; control, $13.5 \pm 0.7 \mathrm{pA}$; lesion, $16.5 \pm 0.9 \mathrm{pA}, p<0.05$, paired $t$ test; $n=11$ and 12 neurons, respectively). The distribution of a random sample of mEPSC amplitudes showed a rightward shift with fewer small events (5-15 pA) and more large events (15-50 pA; Fig. 6B, center panel, $p<0.0001, \mathrm{KS}$ test). The rise time of mEPSCs was also shorter (Fig. $6 \mathrm{~V}$, right; control, $1.46 \pm 0.08 \mathrm{~ms}$; lesion, $1.21 \pm 0.06 \mathrm{~ms}$, $p<0.01$, paired $t$ test; $n=11$ and 12 neurons, respectively). The distribution of rise-times showed a leftward shift with an increase in fast-rising $(0-1.5 \mathrm{~ms})$ and a decrease in slow-rising $(1.5-3 \mathrm{~ms})$ events (Fig. $6 C$, middle; $p<0.0001$, KS test). The larger, more rapidly rising mEPSCs in the denervated dentate gyrus may indicate preferential input from synapses in the inner molecular layer that are closer to the somatic recording site. These results are control lesion
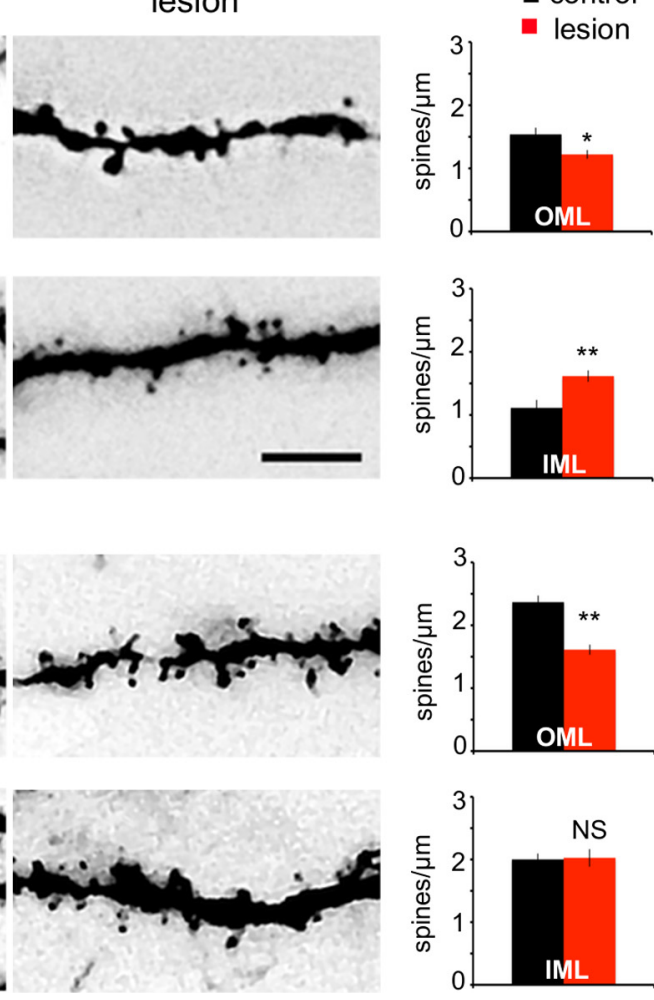

Figure 7. Newborn granule cells showed layer-specific spine formation following lesion. $\boldsymbol{A}$, Newborn granule cells at 21 days postlesion. Newly formed dendritic spines on 21-day-old granule cells were present both in the OML (top) and the IML (bottom). (bottom). In 0.05 ), but significantly higher than control in the IML (bottom right, $p<0.01$ ). $\boldsymbol{B}$, Mature granule cells at 21 days postlesion. Distal dendritic spines on mature granule cells were denervated by the lesion and were decreased in number (top middle) relative to the deafferented region (top right, $p<0.01$ ) than those in the control hemisphere, but no change was observed in the inner molecular layer (bottom right, NS). 0ML, Outer molecular layer; IML, inner molecular layer, ${ }^{*} p<0.05,{ }^{* *} p<0.01$. Scale bar, $5 \mu \mathrm{m}$.

consistent with the lack of vGlut1/2 staining in the denervated zone and thus the absence of sprouting across laminar boundaries (Fig. 1).

\section{De novo dendritic spines in the denervated zone}

The perforant path forms excitatory axons onto dendritic spines of mature granule cells. Following lesioning, dendritic spines are transiently reduced (Matthews et al., 1976a; Steward and Vinsant, 1983; Vuksic et al., 2011). We compared the impact of lesioning on preexisting dendritic spines on mature granule cells with its impact on de novo formation of dendritic spines on newborn neurons. Mature and newborn granule cells were GFP labeled on the day of the lesion with retroviral (pRubi) and lentiviral (FUGW) vectors, respectively. At 21 days postlesion, newborn neurons in the contralateral control had a large number of dendritic spines in the outer molecular layer (Fig. 7A, top left). However there were fewer newly formed spines on the lesioned side (Fig. $7 A$, top right; control, $1.53 \pm 0.17$ spines $/ \mu \mathrm{m}$; lesion, $1.22 \pm$ 0.12 spines $/ \mu \mathrm{m}, p<0.001$, GLM; $n=7$ animals). There was a similar reduction in the number of existing spines on mature granule cells following deafferentation (Fig. $7 B$, top row; control, $2.36 \pm 0.18$ spines $/ \mu \mathrm{m}$; lesion, $1.61 \pm 0.13$ spines $/ \mu \mathrm{m}, p<0.001$, GLM; $n=5$ animals). In contrast, there was a $45 \%$ increase in dendritic spines on newborn neurons in the inner molecular 

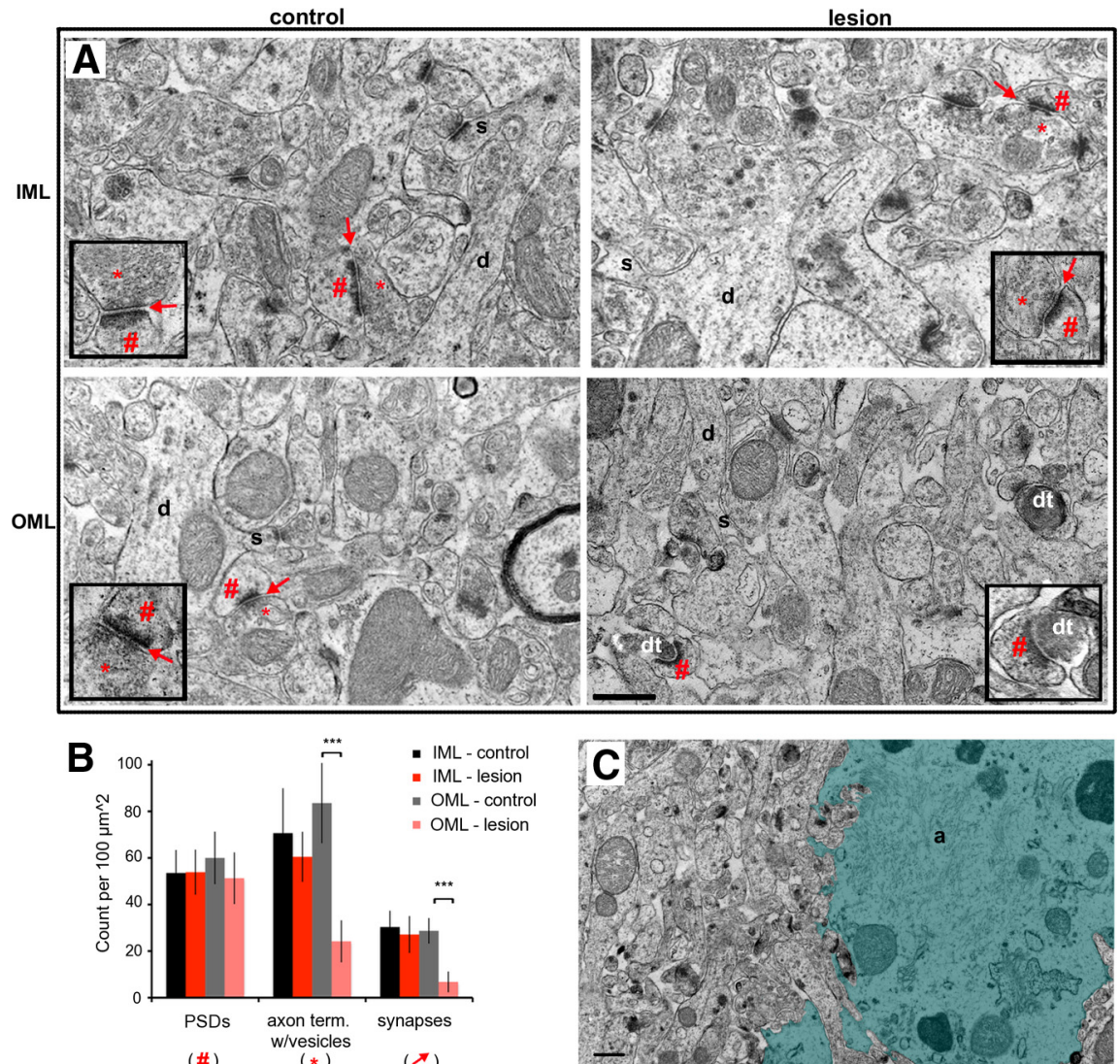

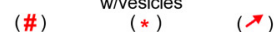

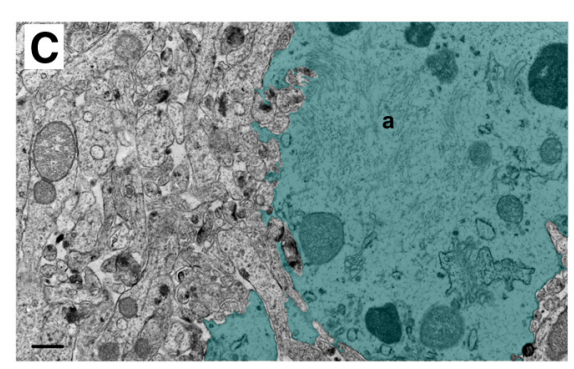

Figure 8. Perforant path lesion decreased the number of presynaptic terminals and intact synapses in the denervated zone. $\boldsymbol{A}$ Top, Electron micrographs of the nondenervated IML at 21 days postlesion showed normal tissue structure in the control (left) and lesioned (right) dentate gyrus. Both dentate gyri had synaptic vesicles/axon terminals $\left(^{*}\right.$ ) at intact synapses (arrow) with postsynaptic densities (\#). Bottom, Electron micrographs of the denervated OML (right) as compared with the outer molecular layer on the contralateral control hemisphere (left). In contrast to the control, the denervated region was devoid of presynaptic terminals $\left(^{*}\right)$ and instead showed electron-dense degenerating axons (dt) apposed to postsynaptic densities (\#). Insets show more examples at higher magnification. $\boldsymbol{B}$, The synaptic composition in the inner and outer molecular layers was quantified by independently counting the number of postsynaptic densities (\#), the number of axon terminals (as indicated by presence of vesicles, ${ }^{*}$ ), and the number of intact synapses (arrows). At 21 days postlesion, the number of postsynaptic densities was unchanged in either layer. Presynaptic terminals and intact synapses were substantially decreased in the denervated $0 \mathrm{ML}(p<0.001)$ but unchanged in the nondenervated IML (NS). C, Low-magnification micrograph (6800×) exemplifying reactive astrogliosis in the denervated outer molecular layer. Reactive astrocytes could occupy as much as 50\% of the most severely affected regions (shaded). IML, Inner molecular layer; $0 \mathrm{ML}$, outer molecular layer; $\mathrm{d}$, dendrite; $s$, dendritic spine; $\mathrm{dt}$, degenerating axon terminal; a, astrocyte. Scale bars, $500 \mathrm{~nm}$. ${ }^{* *} p<0.001$.

layer (Fig. $7 A$, bottom row; control, $1.11 \pm 0.17$ spines $/ \mu \mathrm{m}$; lesion, $1.61 \pm 0.12$ spines $/ \mu \mathrm{m}, p<0.001$, GLM; $n=7$ animals $)$. Mature granule cells, however, did not show a change in spine density in the inner molecular layer (Fig. 7B, bottom; control, $2 \pm$ 0.16 spines $/ \mu \mathrm{m}$; lesion, $2.02 \pm 0.23$ spines/ $\mu \mathrm{m}$, NS, GLM; $n=5$ animals). These results indicate that, following lesion, spine formation on newborn granule cells can occur throughout the molecular layer, but it was most robust in areas that had intact glutamatergic axons.

We were surprised that newborn granule cells developed dendritic spines in the outer molecular layer in the absence of functional perforant path activity as measured by the field EPSPs. Likewise, mature granule cells show an initial decrease in spines following perforant path lesion, but they have been reported to nearly completely recover (Steward and Vinsant, 1983; Vuksic et al., 2011). To evaluate whether these spines are associated with presynaptic terminals, we examined the synaptic ultrastructure in the suprapyramidal blade of the dentate gyrus at 21 days postlesion. In the dentate gyrus contralateral to the lesion, intact asymmetric (excitatory) synapses with presynaptic terminals and postsynaptic densities were easily apparent throughout the molecular layer (Fig. 8A, left), as well as the inner molecular layer in the lesioned hemisphere (Fig. 8A, top right). However, synaptic structures were disrupted in the denervated zone. Degenerating nerve terminals were electron dense and without clearly defined presynaptic vesicles, whereas postsynaptic densities were preserved (Fig. $8 A$, bottom right). To quantify synaptic structures in each layer, 10 regions of interest from 4 nonadjacent sections in each dentate gyrus were imaged. A synapse was considered intact if there was a presynaptic terminal containing synaptic vesicles, a submembrane postsynaptic density (PSD), and close apposition of presynaptic and postsynaptic membranes. As shown in Figure $8 B$, the number of postsynaptic densities in the outer molecular layer was unaffected by the lesion (PSDs: control, $60 \pm 11 / 100$ $\mu \mathrm{m}^{2}$; lesion, $51 \pm 11 / 100 \mu \mathrm{m}^{2}$, NS, paired $t$ test; $n=4$ animals, 10 regions of interest from 4 nonadjacent sections per dentate gyrus), but presynaptic terminals and intact/normal synapses were markedly decreased in the outer molecular layer of the denervated dentate gyrus (axon terminal with vesicles: control, $85 \pm 17 / 100 \mu^{2}$; lesion: $24 \pm 9 / 100$ $\mu \mathrm{m}^{2}, p<0.001$, paired $t$ test; $n=4$ animals; synapses, control: $28 \pm 5 / 100 \mu \mathrm{m}^{2}$; lesion: $6 \pm 4 / 100 \mu \mathrm{m}^{2}, p<0.001$, paired $t$ test; $n=4$ animals, 10 regions of interest from 4 nonadjacent sections per dentate gyrus). Reactive gliosis was also apparent in the denervated zone as described previously (Hailer et al., 1999; Fig. 8C, shaded region).

Because synapses on newborn neuron constitute only a small fraction of all synapses in the molecular layer, the analysis in Figure 8 largely, if not completely, represents synapses on mature granule cells. The relative retention of postsynaptic structures could simply represent slow turnover of pre-existing PSDs that are no longer innervated. However, the protocol we used for retroviral labeling of newborn neurons samples only new dendritic spines and synapses that formed after the lesion. Thus, to examine whether the dendritic spines on newborn neurons have intact synaptic ultrastructure, we performed immunoelectron microscopy on GFP-labeled newborn neurons using an anti-GFP antibody. Because of the relatively sparse labeling of newborn neurons with the retrovirus, sections of the molecular layer were chosen that contained several labeled dendritic trees (Fig. 9A, black boxes). Occasional dendrites with punctate or electron labeling were seen in the inner and outer molecular layers in the control and deafferented dentate gyrus (Fig. 9B). The low frequency of immunolabeled dendrites precluded a quantitative analysis of spines directly attached to labeled dendrites, and thus we counted the number of postsynaptic densities contiguous with immunolabeled areas. Al- 
though decreased in number, PSDs were found on newly formed dendritic spines in the denervated zone (Fig. 9B, right; control, $71 \pm 10 \mathrm{PSDs} / 100 \mu \mathrm{m}^{2}$; lesion, $38 \pm 6$ PSDs $/ 100 \mu \mathrm{m}^{2} ; n=4$ animals, 10 regions of interest from 4 nonadjacent sections per dentate gyrus); however, they were not associated with normal presynaptic structures (control, $4.4 \pm 1$ presynaptic terminals/100 $\mu \mathrm{m}^{2}$; lesion, 0 terminals $/ 100 \mu \mathrm{m}^{2} ; n=4$ animals, 15 regions of interest from 5 nonadjacent sections per dentate gyrus) or with intact synapses (control, $3 \pm 1$ synapses/100 $\mu \mathrm{m}^{2}$; lesion, 0 synapses $/ 100 \mu \mathrm{m}^{2} ; n=4$ animals, 15 regions of interest from 5 nonadjacent sections per dentate gyrus). Given the semiquantitative nature of this experiment, $p$ values could not be determined.

\section{Discussion}

We used a classic injury model- unilateral lesion of the perforant path - to demonstrate that selective deafferentation of the adult dentate gyrus alters the maturation and functional integration of newborn granule cells. We focused on newborn neurons dividing at the time of lesion and thus evaluated the initial neurogenic response as well as de novo dendritic outgrowth and synaptogenesis in the absence of excitatory input from the entorhinal cortex. This approach allowed us to compare mature granule cells that were denervated by the lesion with newborn granule cells that were never innervated by the perforant path.

\section{An initial neurogenic response to perforant path lesion}

Adult-generated newborn neurons are highly sensitive to environmental and molecular stimuli. For example, exercise and neural activity as well as trophic factors can increase proliferation and survival, whereas severe stress and adrenal steroids decrease neurogenesis (Gould and Tanapat, 1999; Tashiro et al., 2007; Vivar et al., 2012). Brain injury such as trauma, seizures, and ischemia can also stimulate neurogenesis (Bengzon et al., 1997; Liu et al., 1998; Dash et al., 2001; Parent and Lowenstein, 2002). In our experiments a chronic denervating injury triggered proliferation of newborn granule cells, as was also reported following a chemical perforant path lesion (Cameron et al., 1995; Gould and Tanapat, 1997). Although a substantial portion of newborn neurons normally undergo cell death (Kuhn et al., 2005; Sierra et al., 2010), in our experiments the same fraction of newborn cells survived 30 days in the lesioned and nonlesioned hemisphere, indicating that the "extra" new neurons had an equal chance of integrating into the circuit and thus could potentially contribute to repair of the neural circuitry.

The factors contributing to proliferation of new neurons following brain injury are likely multifactorial and context dependent. Reductions in cell spiking and spontaneous activity of mature granule cells typically accompany denervation (Reeves and Steward, 1988; Temple et al., 2003). Previous studies using pharmacological manipulation of NMDA receptors and entorhi- control lesion
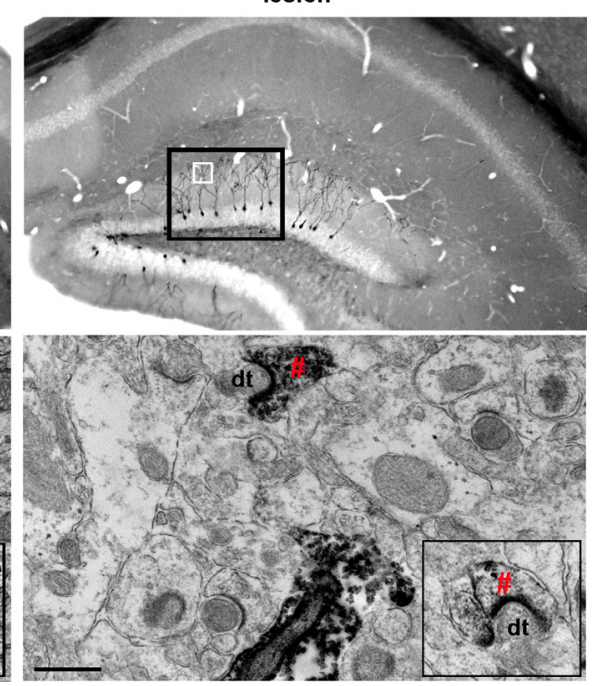

Figure 9. Perforant path lesion did not preclude formation of postsynaptic specializations on newborn granule cell dendrites in the deafferented zone. $A$, Flat embeds of immunostained EM tissue at 21 days postlesion, $40 \mu \mathrm{m}$ sections. Newborn neurons were inperion, thus labeling granule cells that developed in the absence of perforant path straight PSD characteristic of the control. Scale bar (in $\boldsymbol{B}), 500 \mathrm{~nm}$.

nal lesions have suggested an inverse relationship between afferent input and neurogenesis (Cameron et al., 1995; Cameron et al., 1998). In our experiments, mature granule cells were transiently activated by perforant path lesions as detected by c-fos immunoreactivity. However, blocking this burst of activity with MK-801 did not affect lesion-induced proliferation or neurogenesis in the control hemisphere, suggesting that factors other than changes in circuit activity play a role in lesion-induced proliferation. For example, proliferation did correspond with the time of microglial activation in the denervated zone (days 2-3; Gehrmann et al., 1991; Hailer et al., 1999; Dissing-Olesen et al., 2007) and the subsequent appearance of reactive gliosis (day 7, Hailer et al., 1999). Reactive astrocytes produce growth inhibitors as well as trophic factors and growth substrates conducive to regeneration (Sofroniew, 2009; Sofroniew and Vinters, 2010). For example, astrocytes show increased expression of basic fibroblast growth factor following injury (Gómez-Pinilla et al., 1992), thus potentially driving stem cell proliferation, differentiation, and survival (Gage et al., 1995).

\section{Circuit reorganization following denervation}

Although brain injury can stimulate neurogenesis, relatively little is known about postinjury functional integration of newborn neurons. Perforant path lesions have traditionally been used to characterize mature granule cells and the reorganization of their inputs. For example, dendritic complexity and spine density of mature granule cells decrease following removal of the perforant path (Parnavelas et al., 1974; Matthews et al., 1976a; Caceres and Steward, 1983; Diekmann et al., 1996; Schauwecker and McNeill, 1996; Vuksic et al., 2011) despite injury-induced sprouting of 
uninjured pathways (Deller and Frotscher, 1997), including commissural/associational axons (Gall and Lynch, 1981; Schauwecker and McNeill, 1995), septohippocampal cholinergic fibers (Stanfield and Cowan, 1982), and central noradrenergic fibers (Peterson, 1994). However, we examined de novo dendritic outgrowth and spine formation by labeling newborn neurons that were dividing at the time of lesion.

Dendrites of newborn neurons penetrated into the denervated zone but had simpler morphology, indicating that local presynaptic activity is important for developing dendrites (e.g., Tashiro et al., 2006). The simplified morphology of newborn dendrites was comparable to the retraction of distal dendrites in mature granule cells, suggesting that presynaptic activity also plays a role in maintenance of preexisting dendrites (Diekmann et al., 1996). Denervated newborn granule cells were not chronically silenced, as they showed synaptic activation by other pathways at 21 days postlesion. The increase in de novo dendritic spines in the inner molecular layer and the increase in the amplitude and rise time of EPSCs in newborn neurons indicated that excitatory axons could form new synapses with newborn granule cells; however, synaptogenesis appeared to be localized to the uninjured region. Earlier studies in rats reported a partial recovery of excitatory synapses in the denervated outer molecular layer (Matthews et al., 1976b); however, whether this recovery is a result of translaminar sprouting has been controversial (Deller et al., 2001; Del Turco et al., 2003; Phinney et al., 2004). Our experiments in mice indicated that no glutamatergic axons were present in the denervated zone. This discrepancy is likely the result of species differences in the organization of afferents; rats have a crossed entorhinodentate projection that terminates in the outer molecular layer, whereas this projection has not been detected in mice (van Groen et al., 2002; Del Turco et al., 2003; Deller et al., 2007). Whether laminar barriers reflect residual preexisting laminar cues or are produced postlesion by reactive gliosis is not yet clear (Bechmann and Nitsch, 2000; Collazos-Castro and Nieto-Sampedro, 2001; Deller et al., 2001; Deller et al., 2006).

\section{Is a spine a marker of a functional excitatory synapse postlesion?}

The presence of dendritic spines is usually taken as a proxy for the presence of functional glutamatergic excitatory synapses. Dendritic spines on newborn neurons were present in the outer molecular layer in the absence of excitatory input. Importantly, unlike mature neurons, spines on newborn neurons formed $>2$ weeks after the lesion. Thus, at least in the setting of denervation, dendritic spines can form on newborn neurons without intact perforant path axon terminals. In addition, a substantial number of dendritic spines on mature cells in the outer molecular layer were present 3 weeks after denervation, which may represent either maintenance of existing spines or formation of new spines. Interestingly, postsynaptic specializations (junctional folds) at the frog neuromuscular junction are maintained following denervation (Birks et al., 1960), possibly because perisynaptic Schwann cells come in direct contact with denervated junctional folds, release acetylcholine, and trigger small postsynaptic potentials (Katz and Miledi, 1959; Miledi and Slater, 1968). Spine densities on mature granule cells in vivo have been reported to recover to near normal level by 30-180 days postlesion (Parnavelas et al., 1974; Caceres and Steward, 1983; Vuksic et al., 2011), although it is not clear whether regeneration requires presynaptic input. Studies of weaver mice, which lack presynaptic parallel fibers, indicate that dendritic spines can form on deafferented cerebellar Purkinje cells (Hirano and Dembitzer, 1973; Sotelo,
1990). Similarly, in vitro denervation of mature granule cells in organotypic entorhinohippocampal cultures did not affect new spine formation, but the authors observed changes in spine stability and synaptic activity (Vlachos et al., 2012a, Vlachos et al., 2012b). In our in vivo experiments there was no evidence of intact presynaptic terminals in the denervated zone at 21 days postlesion. Thus, mature granule cells can retain and regenerate spines postlesion, whereas newborn neurons do not require perforant path input for spine formation in the outer molecular layer.

It is interesting to consider signals that substitute for presynaptic terminals in the induction of de novo dendritic spines or in the maintenance of mature spines following denervation. As the tissue reacts to neural injury, the environment for dendritic spine and synapse formation may be markedly different from normal development (Mori et al., 2005). For example, in addition to glutamatergic inputs, other transmitters-including GABAergic or cholinergic inputs-could serve as trophic signals following injury (Lauder, 1993; Ben-Ari, 2002; Overstreet-Wadiche et al., 2005). It is also possible that signals from reactive astrocytes or microglia that invade the denervated zone could induce or maintain dendritic spines. For example, glia-derived signals might be neurotransmitters or trophic factors (Sofroniew and Vinters, 2010), as well as extracellular matrix proteins such as thrombospondins (Möller et al., 1996; Christopherson et al., 2005) or matrix metalloproteinases (Warren et al., 2012).

\section{Limits to growth}

Adult-generated newborn neurons can navigate the adult environment and integrate into neural circuits. In our experiments, the net effect of the denervating injury on newborn neurons was to promote an increase in newborn neurons consistent with the potentially positive influences of the injured environment on neural regeneration and repair. Furthermore, newly produced granule cells showed enhanced structural plasticity. Specifically, newborn granule cells had an altered distribution of dendritic spines postlesion, presumably to accommodate sprouting of intact commissural/associational fibers (Matthews et al., 1976b). Given their enhanced short-term plasticity (Schmidt-Hieber et al., 2004), newborn neurons may out-recruit mature cells for sprouting collaterals and may thus have an advantage in de novo synaptogenesis and circuit reorganization. Although de novo spines on newborn neurons appeared ready and willing to accept new synapses, laminar barriers in the dentate gyrus limit full repair of the excitatory network.

\section{References}

Abrous DN, Koehl M, Le Moal M (2005) Adult neurogenesis: from precursors to network and physiology. Physiol Rev 85:523-569. CrossRef Medline

Balu DT, Lucki I (2009) Adult hippocampal neurogenesis: regulation, functional implications, and contribution to disease pathology. Neurosci Biobehav Rev 33:232-252. CrossRef Medline

Bechmann I, Nitsch R (2000) Involvement of non-neuronal cells in entorhinal-hippocampal reorganization following lesions. Ann N Y Acad Sci 911:192-206. CrossRef Medline

Ben-Ari Y (2002) Excitatory actions of GABA during development: the nature of the nurture. Nat Rev Neurosci 3:728-739. CrossRef Medline

Bengzon J, Kokaia Z, Elmér E, Nanobashvili A, Kokaia M, Lindvall O (1997) Apoptosis and proliferation of dentate gyrus neurons after single and intermittent limbic seizures. Proc Natl Acad Sci U S A 94:10432-10437. CrossRef Medline

Birks R, Katz B, Miledi R (1960) Physiological and structural changes at the amphibian myoneural junction, in the course of nerve degeneration. J Physiol 150:145-168. Medline

Boulland JL, Jenstad M, Boekel AJ, Wouterlood FG, Edwards RH, StormMathisen J, Chaudhry FA (2009) Vesicular glutamate and GABA trans- 
porters sort to distinct sets of vesicles in a population of presynaptic terminals. Cereb Cortex 19:241-248. CrossRef Medline

Caceres A, Steward O (1983) Dendritic reorganization in the denervated dentate gyrus of the rat following entorhinal cortical lesions: a Golgi and electron microscopic analysis. J Comp Neurol 214:387-403. CrossRef

Cameron HA, McKay RD (2001) Adult neurogenesis produces a large pool of new granule cells in the dentate gyrus. J Comp Neurol 435:406-417. CrossRef Medline

Cameron HA, McEwen BS, Gould E (1995) Regulation of adult neurogenesis by excitatory input and NMDA receptor activation in the dentate gyrus. J Neurosci 15:4687-4692. Medline

Cameron HA, Tanapat P, Gould E (1998) Adrenal steroids and N-methylD-aspartate receptor activation regulate neurogenesis in the dentate gyrus of adult rats through a common pathway. Neuroscience 82:349-354. CrossRef Medline

Christopherson KS, Ullian EM, Stokes CC, Mullowney CE, Hell JW, Agah A, Lawler J, Mosher DF, Bornstein P, Barres BA (2005) Thrombospondins are astrocyte-secreted proteins that promote CNS synaptogenesis. Cell 120:421-433. CrossRef Medline

Collazos-Castro JE, Nieto-Sampedro M (2001) Developmental and reactive growth of dentate gyrus afferents: cellular and molecular interactions. Restor Neurol Neurosci 19:169-187. Medline

Dash PK, Mach SA, Moore AN (2001) Enhanced neurogenesis in the rodent hippocampus following traumatic brain injury. J Neurosci Res 63:313-319. CrossRef Medline

Dayer AG, Ford AA, Cleaver KM, Yassaee M, Cameron HA (2003) Shortterm and long-term survival of new neurons in the rat dentate gyrus. J Comp Neurol 460:563-572. CrossRef Medline

Deller T, Frotscher M (1997) Lesion-induced plasticity of central neurons: sprouting of single fibres in the rat hippocampus after unilateral entorhinal cortex lesion. Prog Neurobiol 53:687-727. CrossRef Medline

Deller T, Nitsch R, Frotscher M (1996) Layer-specific sprouting of commissural fibres to the rat fascia dentata after unilateral entorhinal cortex lesion: a Phaseolus vulgaris leucoagglutinin tracing study. Neuroscience 71:651-660. CrossRef Medline

Deller T, Haas CA, Frotscher M (2001) Sprouting in the hippocampus after entorhinal cortex lesion is layer-specific but not translaminar: which molecules may be involved? Restor Neurol Neurosci 19:159-167. Medline

Deller T, Haas CA, Freiman TM, Phinney A, Jucker M, Frotscher M (2006) Lesion-induced axonal sprouting in the central nervous system. Adv Exp Med Biol 557:101-121. CrossRef Medline

Deller T, Del Turco D, Rappert A, Bechmann I (2007) Structural reorganization of the dentate gyrus following entorhinal denervation: species differences between rat and mouse. Prog Brain Res 163:501-528. CrossRef Medline

Del Turco D, Woods AG, Gebhardt C, Phinney AL, Jucker M, Frotscher M, Deller T (2003) Comparison of commissural sprouting in the mouse and rat fascia dentata after entorhinal cortex lesion. Hippocampus 13: 685-699. CrossRef Medline

Diekmann S, Ohm TG, Nitsch R (1996) Long-lasting transneuronal changes in rat dentate granule cell dendrites after entorhinal cortex lesion. A combined intracellular injection and electron microscopy study. Brain Pathol 6:205-215. CrossRef Medline

Dissing-Olesen L, Ladeby R, Nielsen HH, Toft-Hansen H, Dalmau I, Finsen B (2007) Axonal lesion-induced microglial proliferation and microglial cluster formation in the mouse. Neuroscience 149:112-122. CrossRef Medline

Gage FH, Coates PW, Palmer TD, Kuhn HG, Fisher LJ, Suhonen JO, Peterson DA, Suhr ST, Ray J (1995) Survival and differentiation of adult neuronal progenitor cells transplanted to the adult brain. Proc Natl Acad Sci U S A 92:11879-11883. CrossRef Medline

Gall C, Lynch G (1981) Fiber architecture of the dentate gyrus following ablation of the entorhinal cortex in rats of different ages: evidence for two forms of axon sprouting in the immature brain. Neuroscience 6:903-910. CrossRef Medline

Ge S, Sailor KA, Ming GL, Song H (2008) Synaptic integration and plasticity of new neurons in the adult hippocampus. J Physiol 586:3759-3765. CrossRef Medline

Gehrmann J, Schoen SW, Kreutzberg GW (1991) Lesion of the rat entorhinal cortex leads to a rapid microglial reaction in the dentate gyrus. Acta Neuropathol 82:442-455. CrossRef Medline

Gómez-Pinilla F, Lee JW, Cotman CW (1992) Basic FGF in adult rat brain: cellular distribution and response to entorhinal lesion and fimbria-fornix transection. J Neurosci 12:345-355. Medline

Gould E, Tanapat P (1997) Lesion-induced proliferation of neuronal progenitors in the dentate gyrus of the adult rat. Neuroscience 80:427-436. CrossRef Medline

Gould E, Tanapat P (1999) Stress and hippocampal neurogenesis. Biol Psychiatry 46:1472-1479. CrossRef Medline

Haas CA, Frotscher M, Deller T (1999) Differential induction of c-Fos, c-Jun and Jun B in the rat central nervous system following unilateral entorhinal cortex lesion. Neuroscience 90:41-51. CrossRef Medline

Hailer NP, Grampp A, Nitsch R (1999) Proliferation of microglia and astrocytes in the dentate gyrus following entorhinal cortex lesion: a quantitative bromodeoxyuridine-labelling study. Eur J Neurosci 11:3359-3364. CrossRef Medline

Hegarty DM, Tonsfeldt K, Hermes SM, Helfand H, Aicher SA (2010) Differential localization of vesicular glutamate transporters and peptides in corneal afferents to trigeminal nucleus caudalis. J Comp Neurol 518: 3557-3569. CrossRef Medline

Hirano A, Dembitzer HM (1973) Cerebellar alterations in the weaver mouse. J Cell Biol 56:478-486. CrossRef Medline

Hjorth-Simonsen A (1972) Projection of the lateral part of the entorhinal area to the hippocampus and fascia dentata. J Comp Neurol 146:219-232. CrossRef Medline

Hjorth-Simonsen A, Jeune B (1972) Origin and termination of the hippocampal perforant path in the rat studied by silver impregnation. J Comp Neurol 144:215-232. CrossRef Medline

Katz B, Miledi R (1959) Spontaneous subthreshold activity at denervated amphibian end-plates. J Physiol 146:44P-45P.

Kempermann G, Kuhn HG, Gage FH (1997) Genetic influence on neurogenesis in the dentate gyrus of adult mice. Proc Natl Acad Sci U S A 94:10409-10414. CrossRef Medline

Kuhn HG, Biebl M, Wilhelm D, Li M, Friedlander RM, Winkler J (2005) Increased generation of granule cells in adult Bcl-2-overexpressing mice: a role for cell death during continued hippocampal neurogenesis. Eur J Neurosci 22:1907-1915. CrossRef Medline

Lauder JM (1993) Neurotransmitters as growth regulatory signals: role of receptors and second messengers. Trends Neurosci 16:233-240. CrossRef Medline

Leranth C, Hajszan T (2007) Extrinsic afferent systems to the dentate gyrus. Prog Brain Res 163:63-84. CrossRef Medline

Lewis PF, Emerman M (1994) Passage through mitosis is required for oncoretroviruses but not for the human immunodeficiency virus. J Virol 68:510-516. Medline

Liu J, Solway K, Messing RO, Sharp FR (1998) Increased neurogenesis in the dentate gyrus after transient global ischemia in gerbils. J Neurosci 18: 7768-7778. Medline

Lois C, Hong EJ, Pease S, Brown EJ, Baltimore D (2002) Germline transmission and tissue-specific expression of transgenes delivered by lentiviral vectors. Science 295:868-872. CrossRef Medline

Luikart BW, Schnell E, Washburn EK, Bensen AL, Tovar KR, Westbrook GL (2011) Pten knockdown in vivo increases excitatory drive onto dentate granule cells. J Neurosci 31:4345-4354. CrossRef Medline

Luikart BW, Perederiy JV, Westbrook GL (2012) Dentate gyrus neurogenesis, integration and microRNAs. Behav Brain Res 227:348-355. CrossRef Medline

Matthews DA, Cotman C, Lynch G (1976a) An electron microscopic study of lesion-induced synaptogenesis in the dentate gyrus of the adult rat. I. Magnitude and time course of degeneration. Brain Res 115:1-21. CrossRef Medline

Matthews DA, Cotman CW, Lynch G (1976b) An electron microscopic study of lesion-induced synaptogenesis in the dendate gyrus of the adult rat. II. Reappearance of morphologically normal synaptic contacts. Brain Res 115:23-41. CrossRef Medline

Miledi R, Slater CR (1968) Electrophysiology and electron-microscopy of rat neuromuscular junctions after nerve degeneration. Proc R Soc Lond B Biol Sci 169:289-306. CrossRef Medline

Ming GL, Song H (2011) Adult neurogenesis in the mammalian brain: significant answers and significant questions. Neuron 70:687-702. CrossRef Medline

Möller JC, Klein MA, Haas S, Jones LL, Kreutzberg GW, Raivich G (1996) Regulation of thrombospondin in the regenerating mouse facial motor nucleus. Glia 17:121-132. CrossRef Medline 
Mori T, Buffo A, Götz M (2005) The novel roles of glial cells revisited: the contribution of radial glia and astrocytes to neurogenesis. Curr Top Dev Biol 69:67-99. CrossRef Medline

Nacher J, McEwen BS (2006) The role of $N$-methyl-D-asparate receptors in neurogenesis. Hippocampus 16:267-270. CrossRef Medline

Nitsch R, Frotscher M (1992) Reduction of posttraumatic transneuronal "early gene" activation and dendritic atrophy by the N-methyl-Daspartate receptor antagonist MK-801. Proc Natl Acad Sci U S A 89:51975200. CrossRef Medline

Overstreet-Wadiche LS, Westbrook GL (2006) Functional maturation of adult-generated granule cells. Hippocampus 16:208-215. CrossRef Medline

Overstreet LS, Hentges ST, Bumaschny VF, de Souza FS, Smart JL, Santangelo AM, Low MJ, Westbrook GL, Rubinstein M (2004) A transgenic marker for newly born granule cells in dentate gyrus. J Neurosci 24:3251-3259. CrossRef Medline

Overstreet Wadiche L, Bromberg DA, Bensen AL, Westbrook GL (2005) GABAergic signaling to newborn neurons in dentate gyrus. J Neurophysiol 94:4528-4532. CrossRef Medline

Parent JM, Lowenstein DH (2002) Seizure-induced neurogenesis: are more new neurons good for an adult brain? Prog Brain Res 135:121-131. CrossRef Medline

Parent JM, Murphy GG (2008) Mechanisms and functional significance of aberrant seizure-induced hippocampal neurogenesis. Epilepsia 49 [Suppl 5]:19-25. CrossRef Medline

Parnavelas JG, Lynch G, Brecha N, Cotman CW, Globus A (1974) Spine loss and regrowth in hippocampus following deafferentation. Nature 248:71-73. CrossRef Medline

Peterson GM (1994) Sprouting of central noradrenergic fibers in the dentate gyrus following combined lesions of its entorhinal and septal afferents. Hippocampus 4:635-648. CrossRef Medline

Phinney AL, Calhoun ME, Woods AG, Deller T, Jucker M (2004) Stereological analysis of the reorganization of the dentate gyrus following entorhinal cortex lesion in mice. Eur J Neurosci 19:1731-1740. CrossRef Medline

Reeves TM, Steward O (1988) Changes in the firing properties of neurons in the dentate gyrus with denervation and reinnervation: implications for behavioral recovery. Exp Neurol 102:37-49. CrossRef Medline

Schauwecker PE, McNeill TH (1995) Enhanced but delayed axonal sprouting of the commissural/associational pathway following a combined entorhinal cortex/fimbria fornix lesion. J Comp Neurol 351:453-464. CrossRef Medline

Schauwecker PE, McNeill TH (1996) Dendritic remodeling of dentate granule cells following a combined entorhinal cortex/fimbria fornix lesion. Exp Neurol 141:145-153. CrossRef Medline

Schmidt-Hieber C, Jonas P, Bischofberger J (2004) Enhanced synaptic plasticity in newly generated granule cells of the adult hippocampus. Nature 429:184-187. CrossRef Medline

Sierra A, Encinas JM, Deudero JJ, Chancey JH, Enikolopov G, OverstreetWadiche LS, Tsirka SE, Maletic-Savatic M (2010) Microglia shape adult hippocampal neurogenesis through apoptosis-coupled phagocytosis. Cell Stem Cell 7:483-495. CrossRef Medline

Sofroniew MV (2009) Molecular dissection of reactive astrogliosis and glial scar formation. Trends Neurosci 32:638-647. CrossRef Medline

Sofroniew MV, Vinters HV (2010) Astrocytes: biology and pathology. Acta Neuropathol 119:7-35. CrossRef Medline

Sotelo C (1990) Cerebellar synaptogenesis: what we can learn from mutant mice. J Exp Biol 153:225-249. Medline

Stanfield BB, Cowan WM (1982) The sprouting of septal afferents to the dentate gyrus after lesions of the entorhinal cortex in adult rats. Brain Res 232:162-170. CrossRef Medline

Steward O, Vinsant SL (1983) The process of reinnervation in the dentate gyrus of the adult rat: a quantitative electron-microscopic analysis of terminal proliferation and reactive synaptogenesis. J Comp Neurol 214: 370-386. CrossRef

Tashiro A, Sandler VM, Toni N, Zhao C, Gage FH (2006) NMDA-receptormediated, cell-specific integration of new neurons in adult dentate gyrus. Nature 442:929-933. CrossRef Medline

Tashiro A, Makino H, Gage FH (2007) Experience-specific functional modification of the dentate gyrus through adult neurogenesis: a critical period during an immature stage. J Neurosci 27:3252-3259. CrossRef Medline

Temple MD, Worley PF, Steward O (2003) Visualizing changes in circuit activity resulting from denervation and reinnervation using immediate early gene expression. J Neurosci 23:2779-2788. Medline

van Groen T, Kadish I, Wyss JM (2002) Species differences in the projections from the entorhinal cortex to the hippocampus. Brain Res Bull 57:553-556. CrossRef Medline

van Groen T, Miettinen P, Kadish I (2003) The entorhinal cortex of the mouse: organization of the projection to the hippocampal formation. Hippocampus 13:133-149. CrossRef Medline

Vivar C, Potter MC, van Praag H (2012) All about running: synaptic plasticity, growth factors and adult hippocampal neurogenesis. Curr Top Behav Neurosci. Advance online publication. Retrieved July 31, 2012. doi:10.1007/7854_2012_220. CrossRef Medline

Vlachos A, Bas Orth C, Schneider G, Deller T (2012a) Time-lapse imaging of granule cells in mouse entorhino-hippocampal slice cultures reveals changes in spine stability after entorhinal denervation. J Comp Neurol 520:1891-1902. CrossRef Medline

Vlachos A, Becker D, Jedlicka P, Winkels R, Roeper J, Deller T (2012b) Entorhinal denervation induces homeostatic synaptic scaling of excitatory postsynapses of dentate granule cells in mouse organotypic slice cultures. PLoS One 7:e32883. CrossRef Medline

Vuksic M, Del Turco D, Vlachos A, Schuldt G, Müller CM, Schneider G, Deller T (2011) Unilateral entorhinal denervation leads to long-lasting dendritic alterations of mouse hippocampal granule cells. Exp Neurol 230:176-185. CrossRef Medline

Warren KM, Reeves TM, Phillips LL (2012) MT5-MMP, ADAM-10, and $\mathrm{N}$-cadherin act in concert to facilitate synapse reorganization after traumatic brain injury. J Neurotrauma 29:1922-1940. CrossRef Medline 